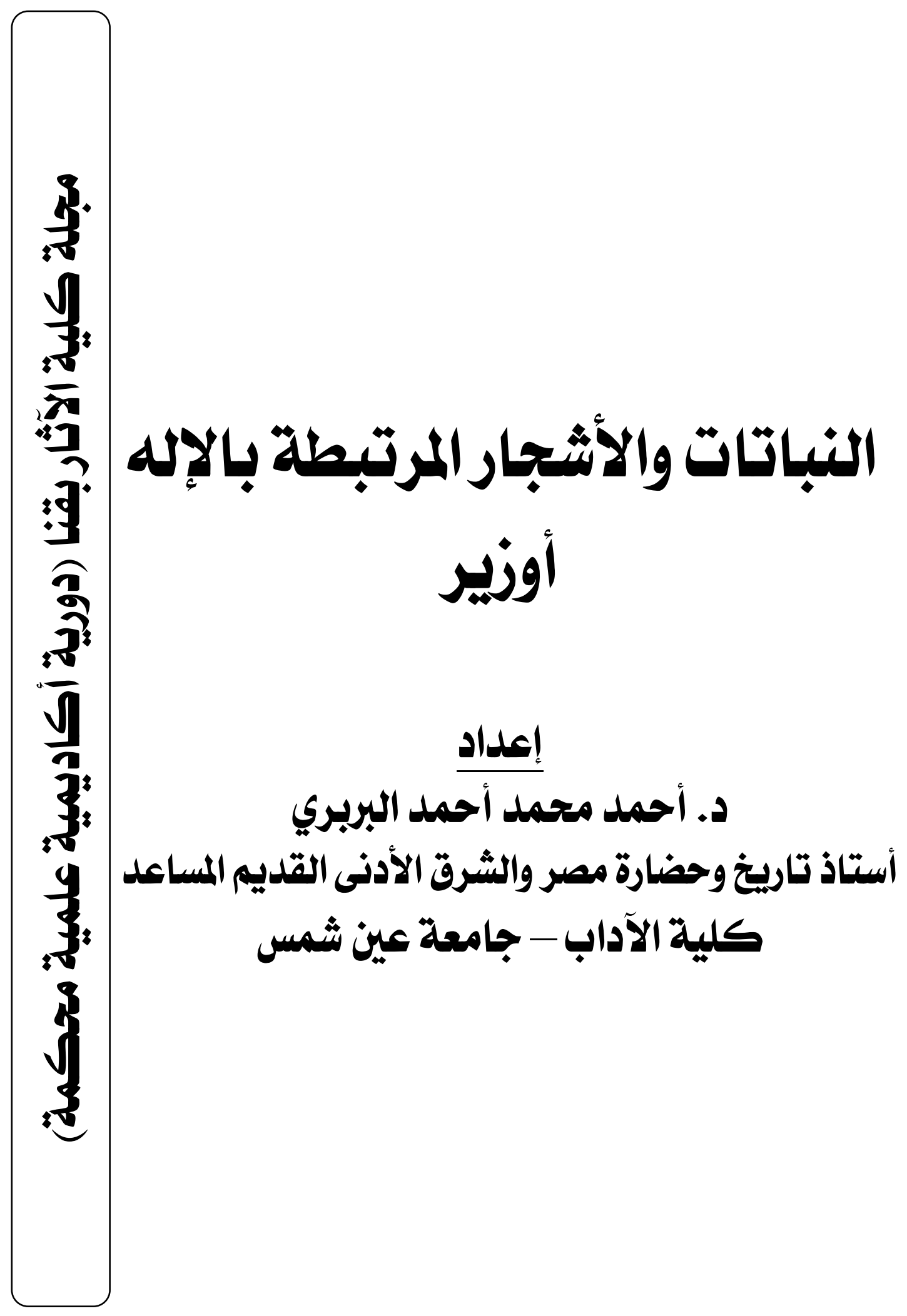



كان الإله "أوزير" من أشهر المعبودات المصرية القديمة، واتخذ الكثير من

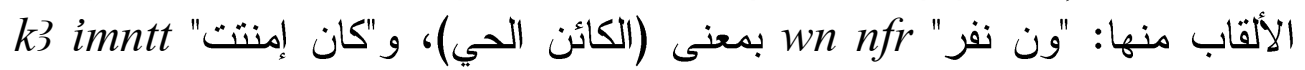

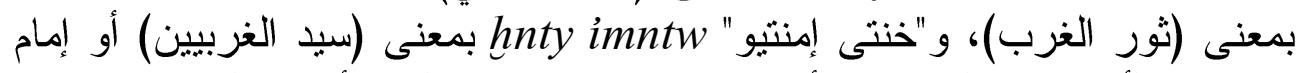

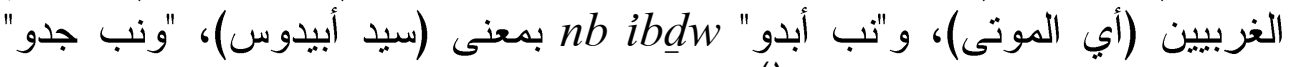

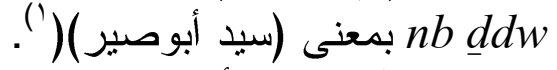
اعثُبر الإله "أوزير" تجسيدًا لكل قوى البعث و الخصوبة و الموت ونبع الحياة

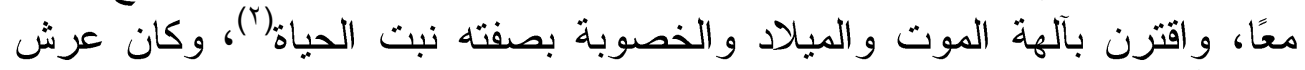

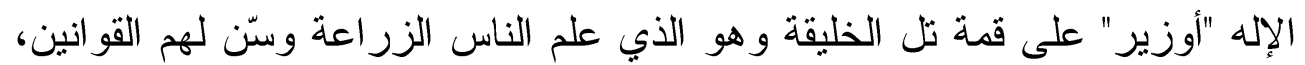

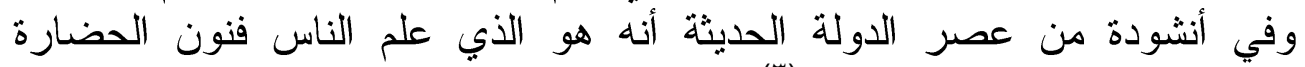
وارتبط بالخصوبة وفن وفيضان النيل (؟).

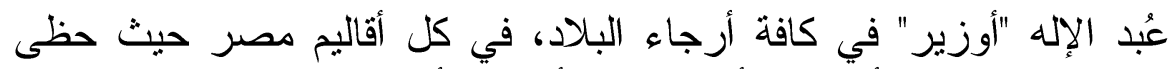

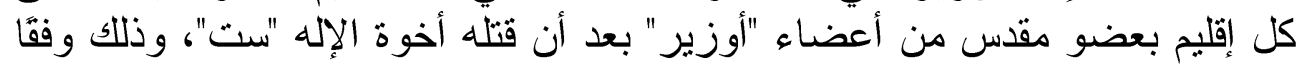

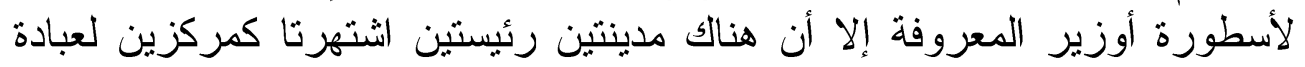

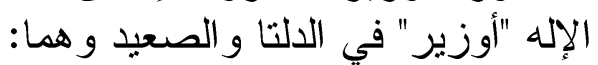

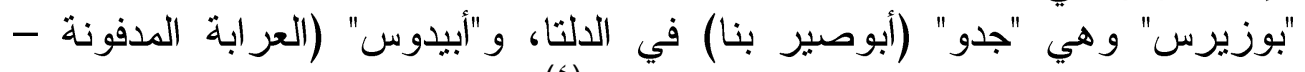

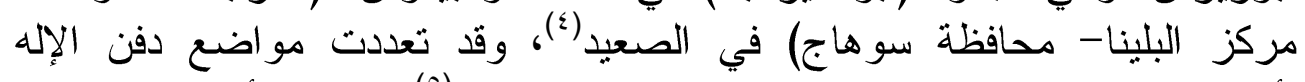

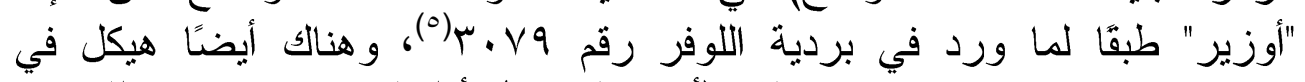

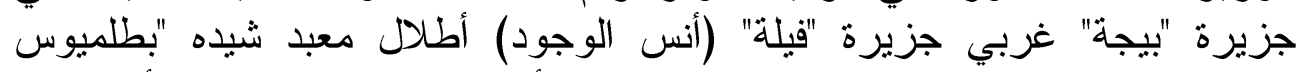

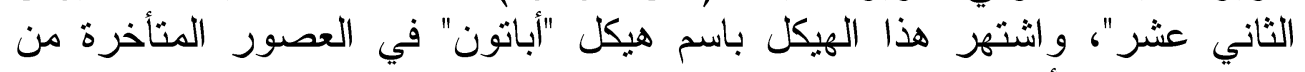

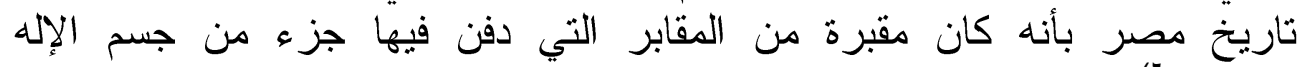

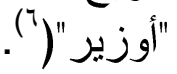

ارتبط الإله "أوزير" بالنيل والفيضان مصدر خصوبة التربة في أرض ألفان

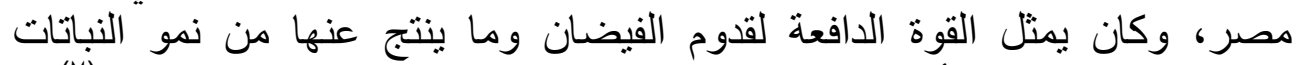

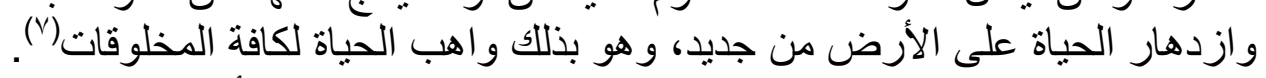

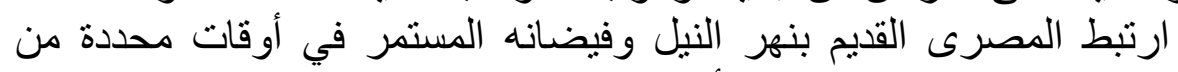

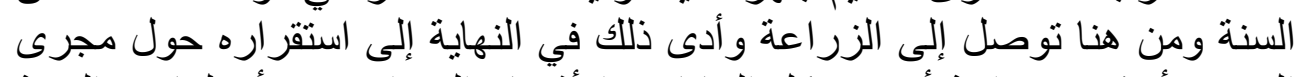

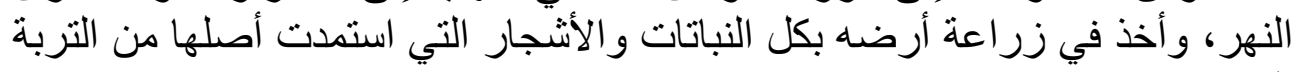
لاحظ المصري القديم من خلال اهتمامه بالنباتات والأشجار التي قام

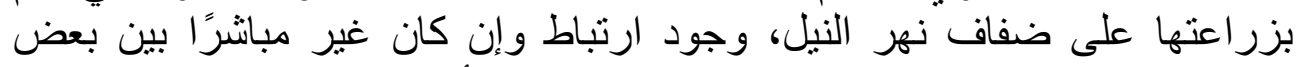

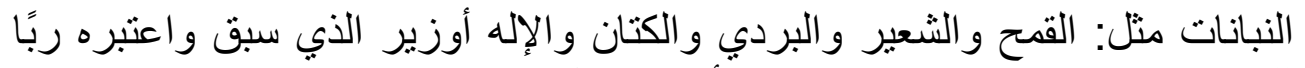

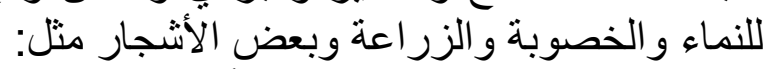

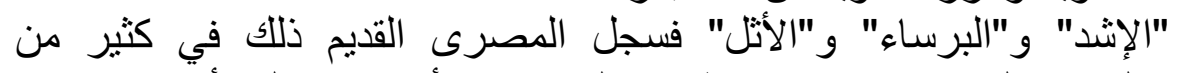

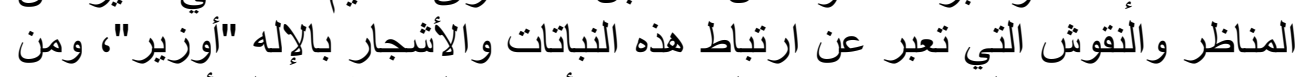

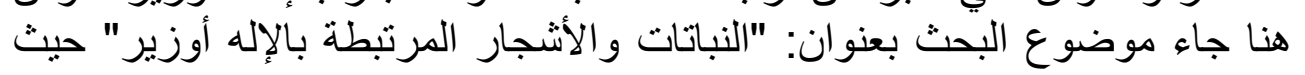


تم معالجة البحث من خلال عرض للنباتات والأشجار السابق ذكرها من حيث التسميات وارتباطها بالإله "أوزير" وبعض المغ المناظر و النقوش التى عبر عن ذلك. وتم تقسيم البحث إلى جزئين:

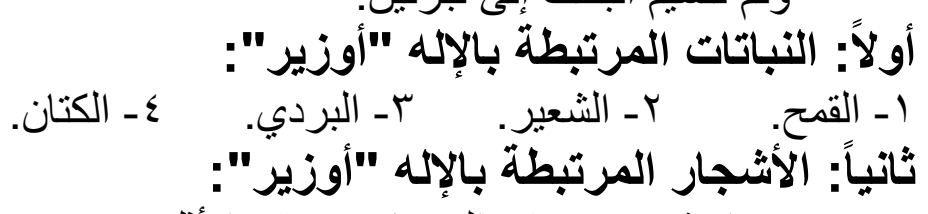

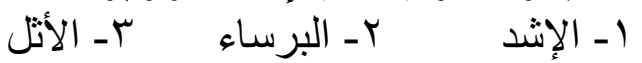

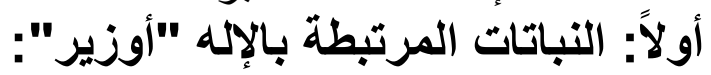

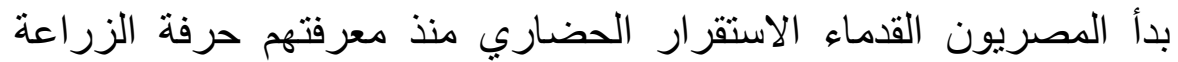

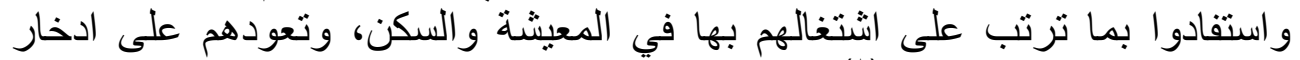
حبوب الزرانة بما ترثب ومحاصيلهياء).

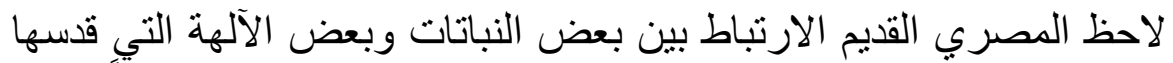

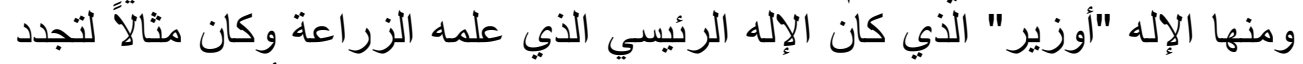

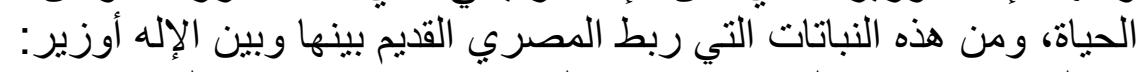
1 القمح 1 - القمح: القع: يُعد القمح من أقدم النباتات التي زُرعت في وادى النيل، ويحتل المكانة الأولى النى

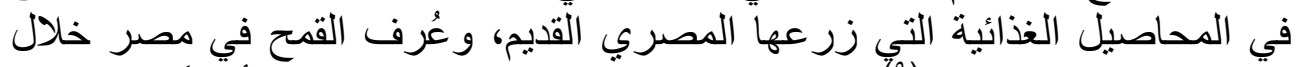

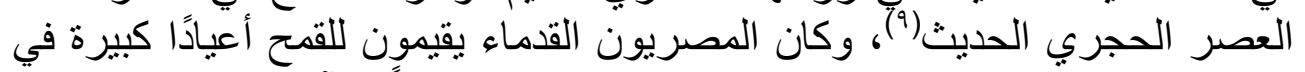

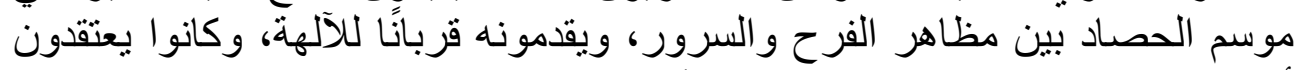

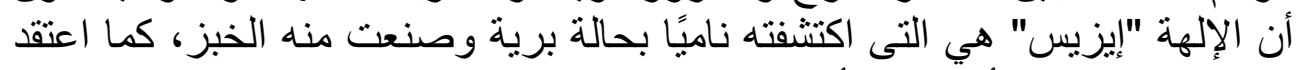

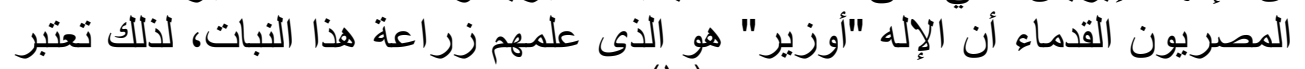

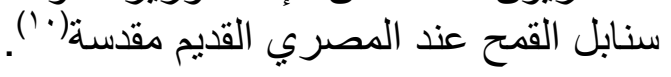

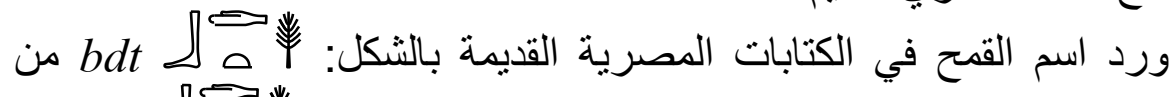

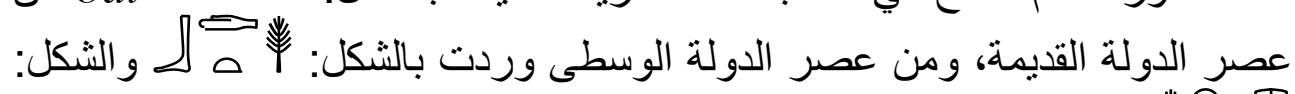

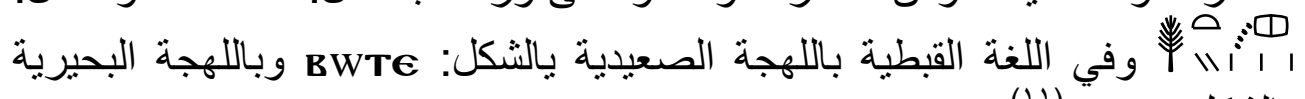

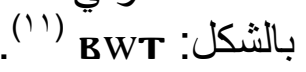
ومن التسميات الأخرى للقمح والتي وردت في نصوص الألهر الهرام من عصر الدولة

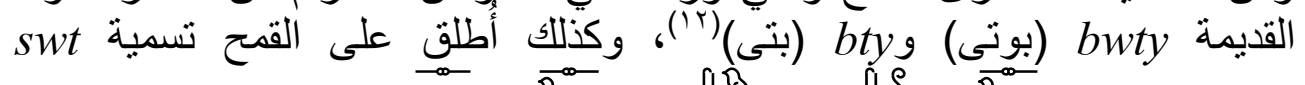

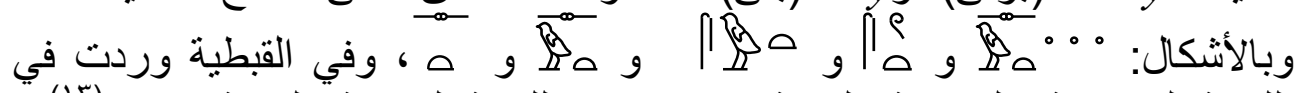

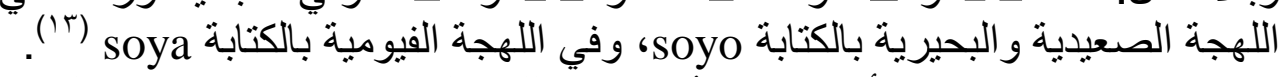

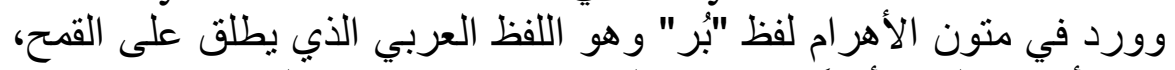

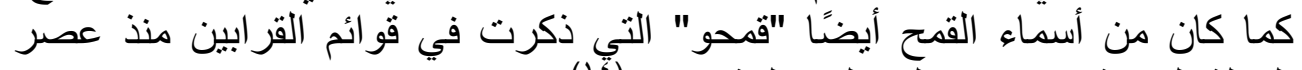

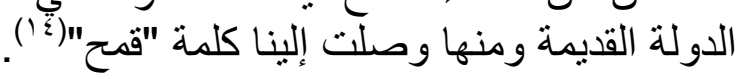


ذكر أحمد كمال باشا أن لفظ قمح هو لفظ مصرى قديم وجد على الآثار

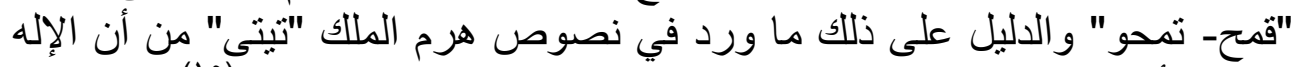

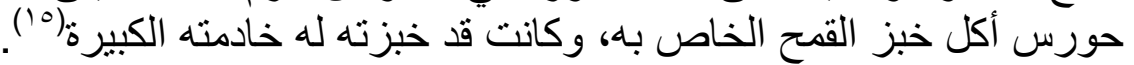

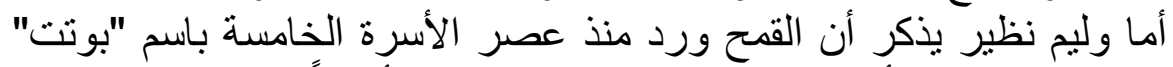

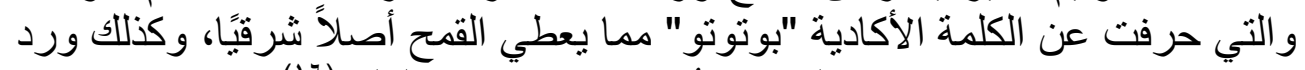

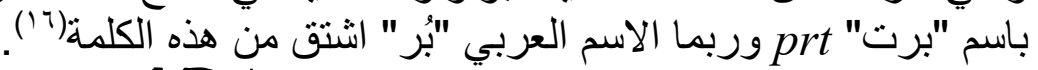

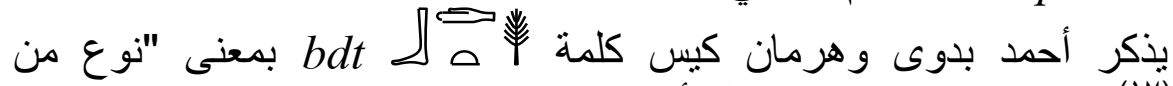

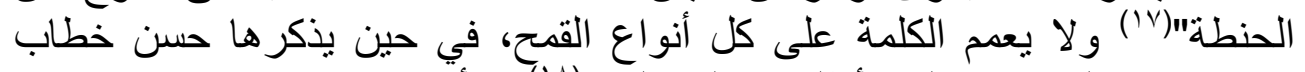

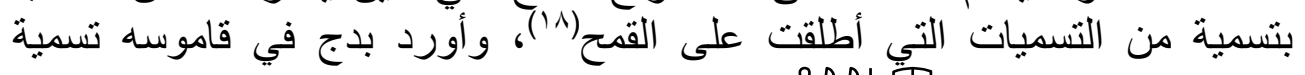

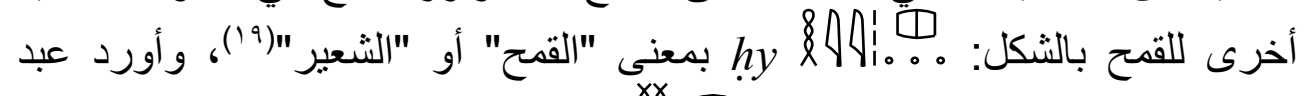

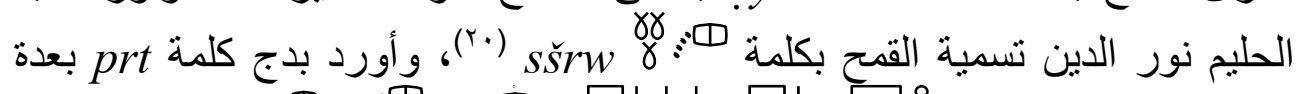

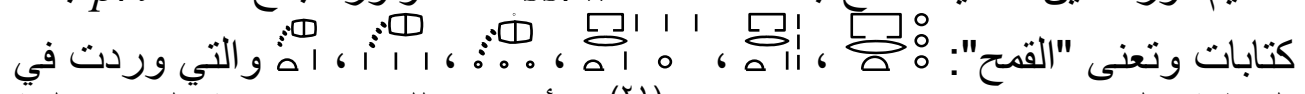

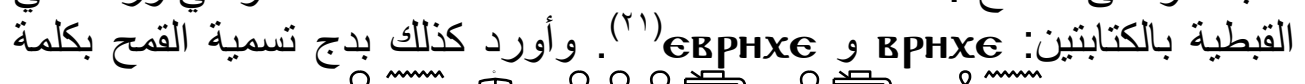

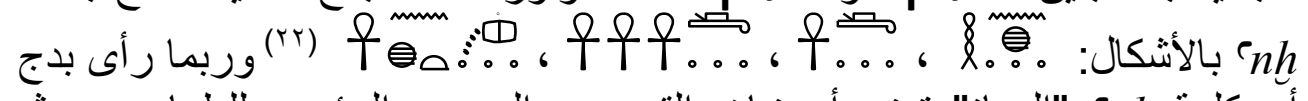

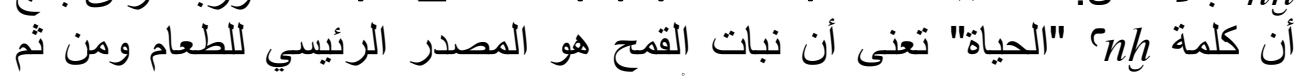

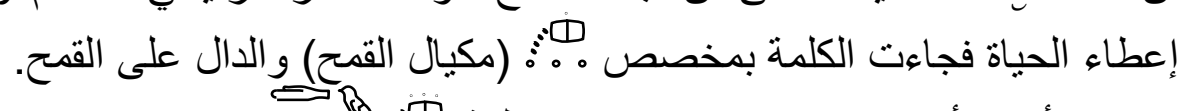

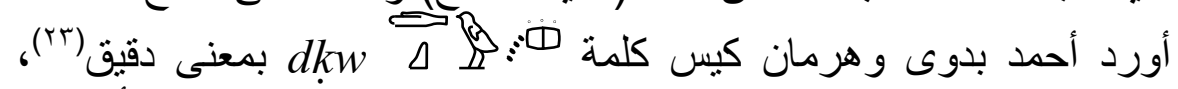

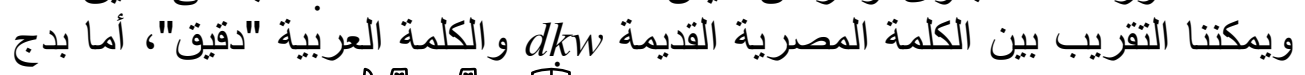

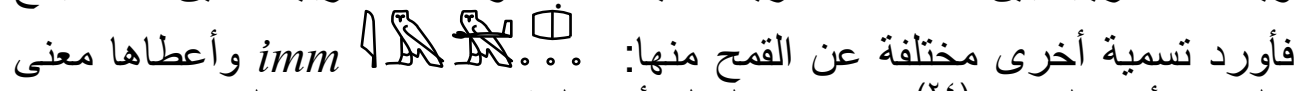

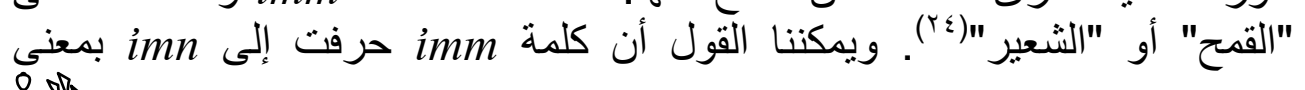

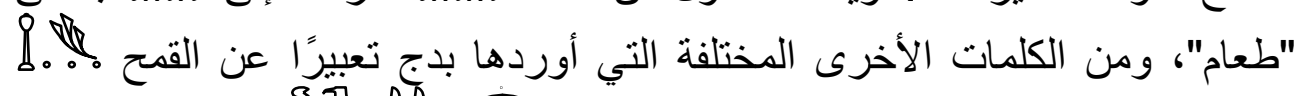
كُ فَث: اللغة العربية كلمة "قوت الكيات من الكتابات السابقة الدالة على أسماء القمح نجد أن المصري القديم وضع

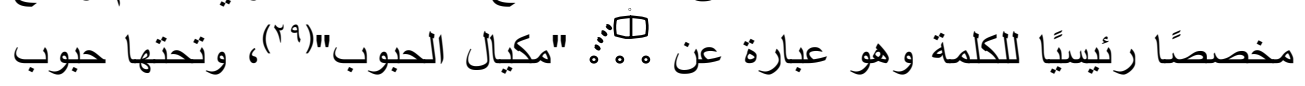

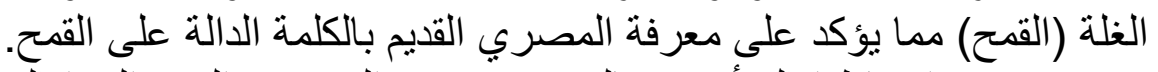

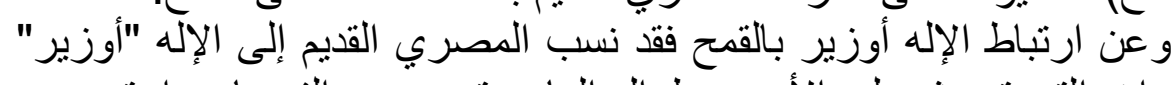

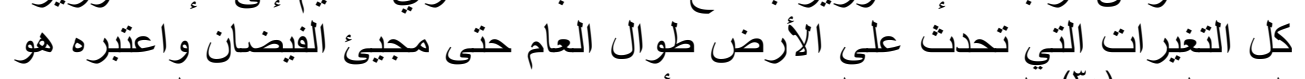

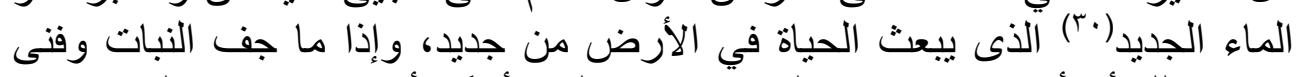

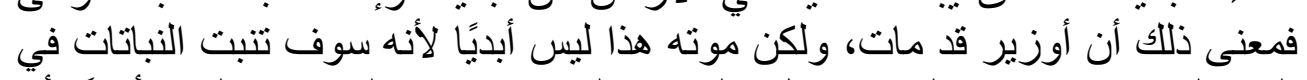

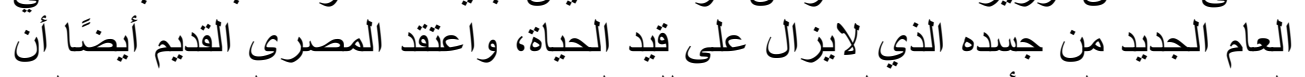

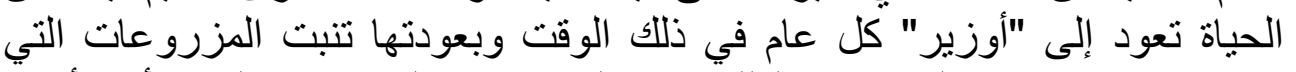

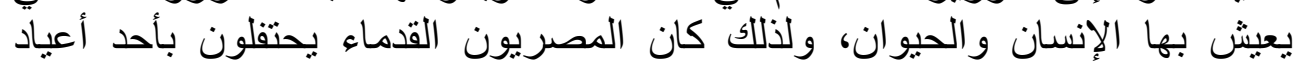


أوزير وتمثيله (وقد عادت إليه الحياة) ببذور نابتة، فكانوا يصورونه ميتًا مستلقيًا

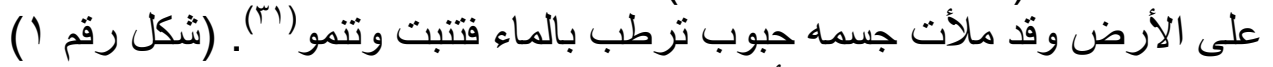

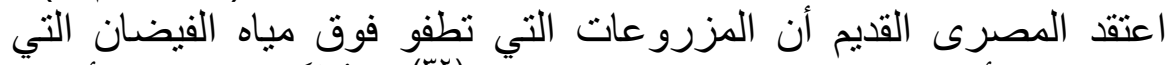

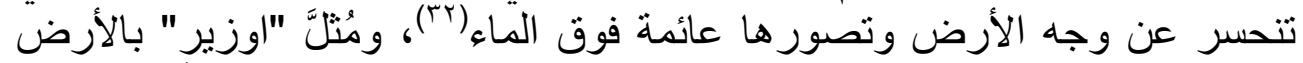

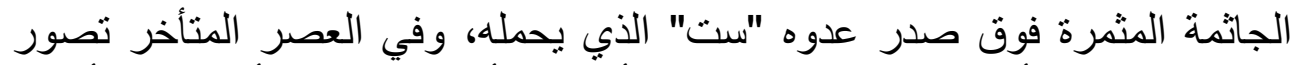

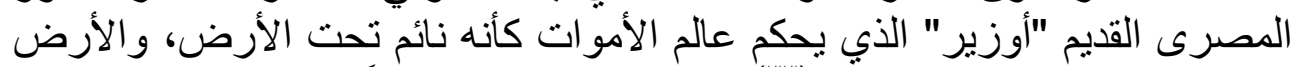

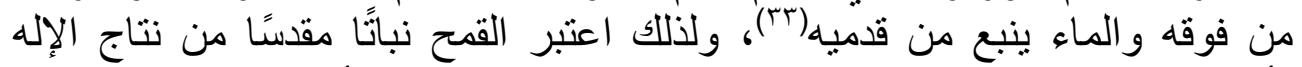

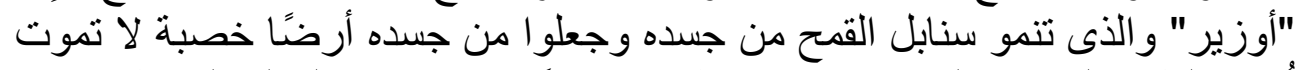

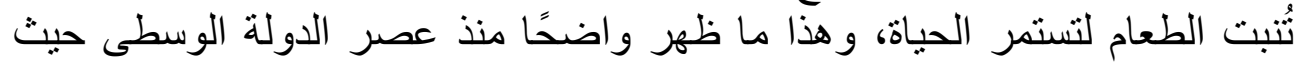

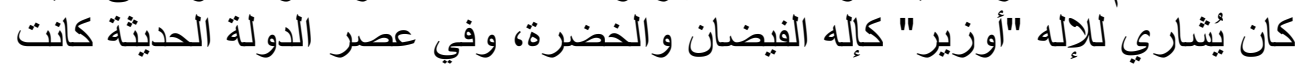

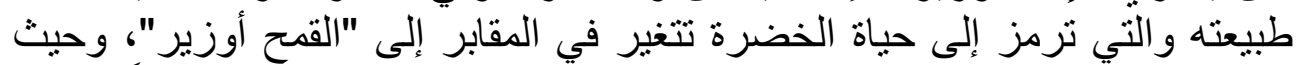

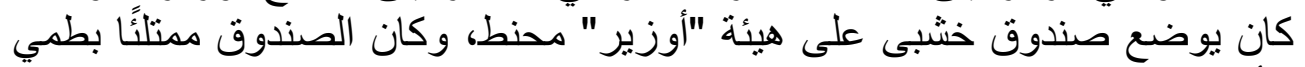

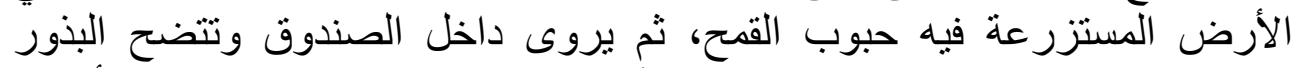

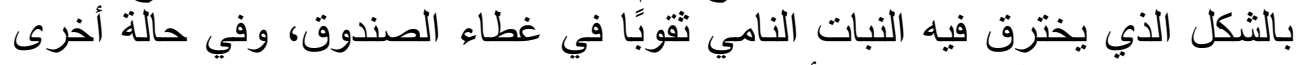

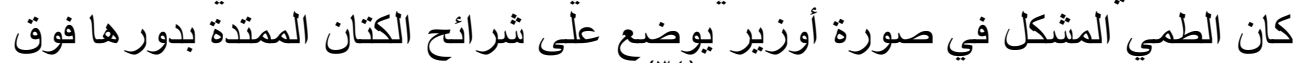

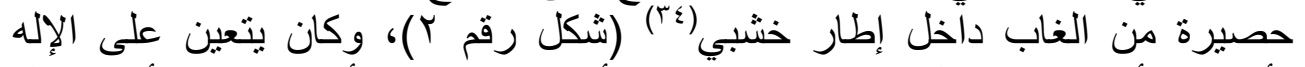

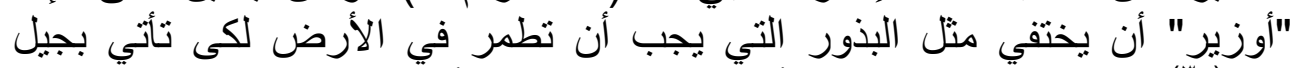

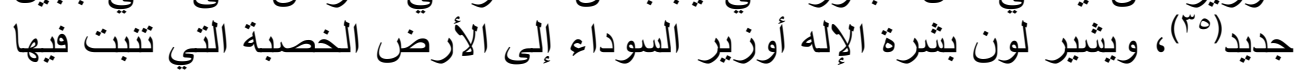

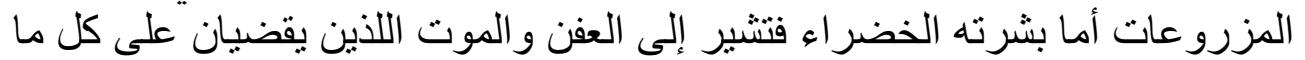
هو قابل للتلف (זن)

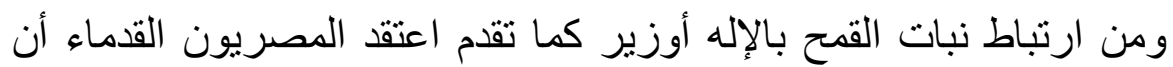

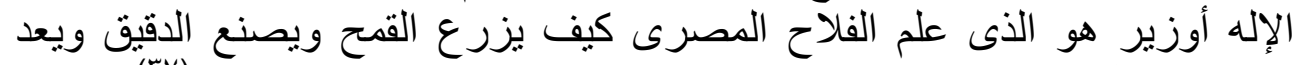

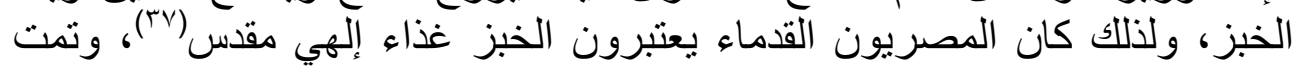

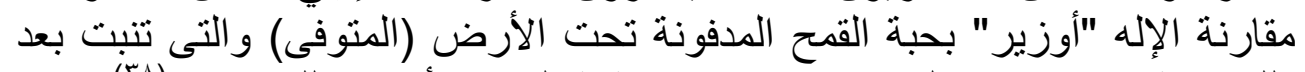

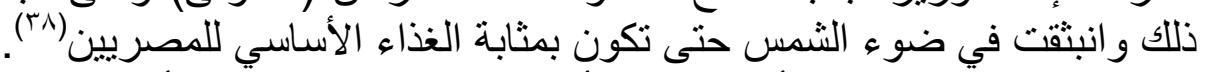

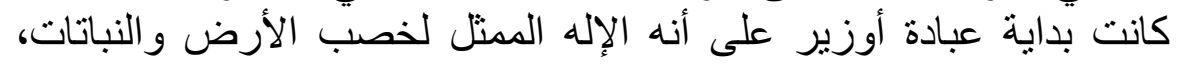

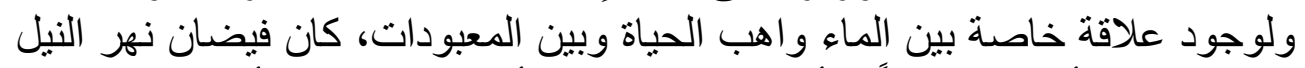

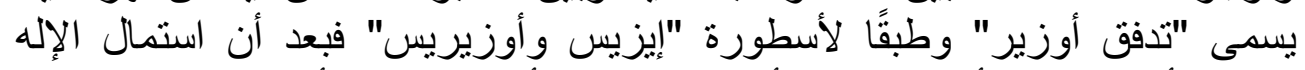

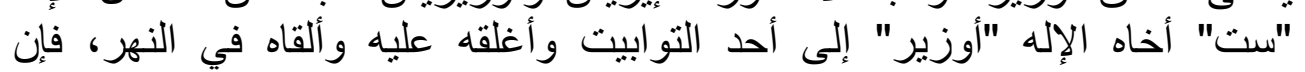

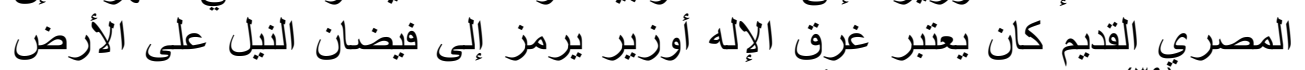

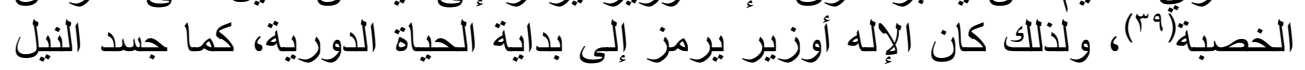

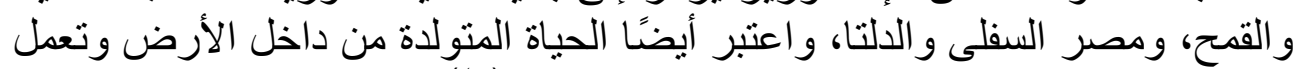

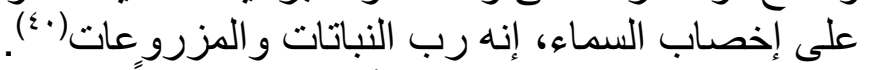

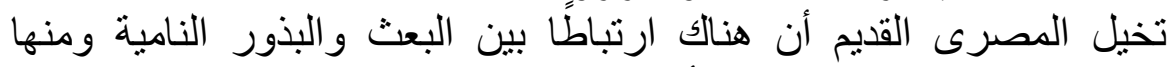

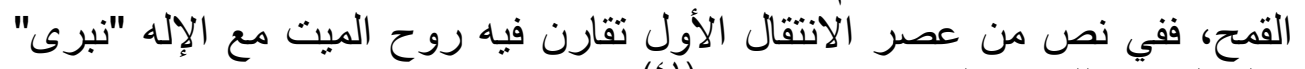

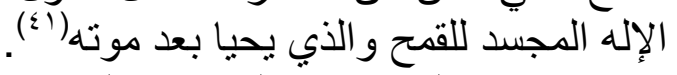

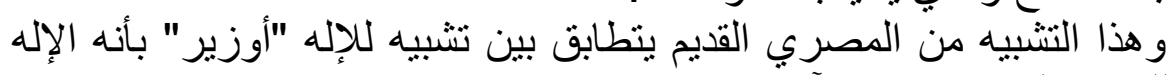

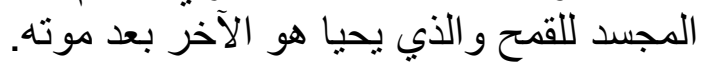




\section{النباتات والأشجار المرتبطة بالإله أوزير}

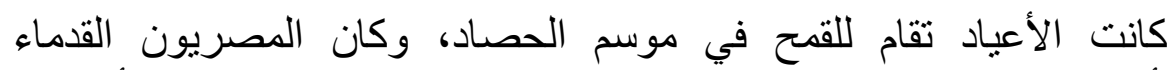

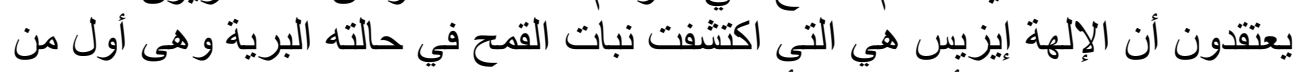

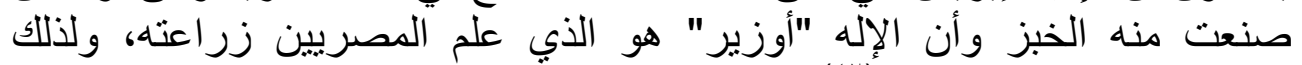
اعتبرت سنابل القمح مقدسة(r٪)، وارتبطت بالإله أوزير، وفي موسم جمع المحصول

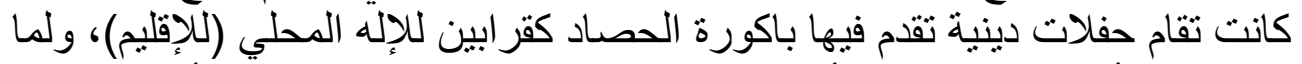
كان الإله "أوزير" إلهًا للقمح أيضًا، كانت الاحتفالات به شائعة في كل أنحاء البلاد، وكان المصريون يصنعون من الطين صورة له يدفنون فيها الحبوب (القهم) وينتهزون فرصة الحصاد لتمثيل المأساة التي مرت بحياة أوزير من قتل وموت ودفن

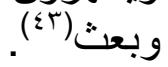

مما سبق يتضح لنا أن نبات القمح كان من النباتات التي ارتبطت بالإله أوزير بعد أن اعتقد المصرى القديم بوجود صلة بين الاثنين من حيثث الموت و الحياة من جديد، لذلك كان يصور في كثير من صور الإله أوزير وقد نبتث فوق جثنه أعو اد القمح دلالة على ارتباط نبات القمح بأوزير.

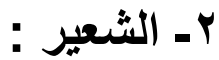

عرف المصريون زراعة الثعير منذ عصور ما قبل الأسرات، وكانوا

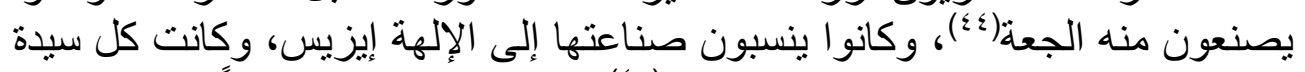

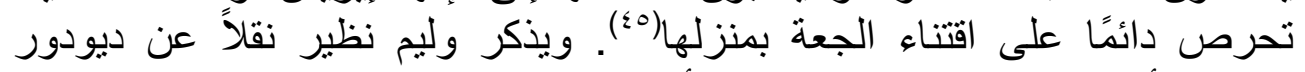

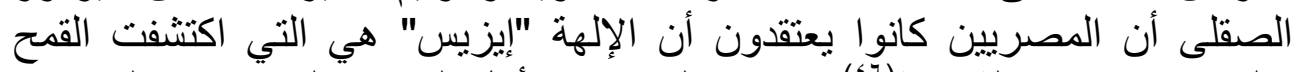

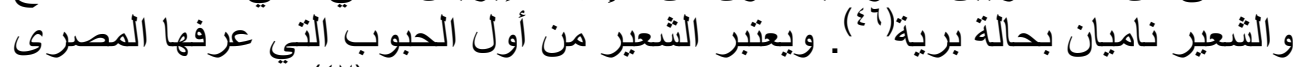

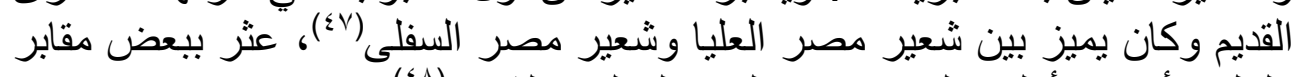

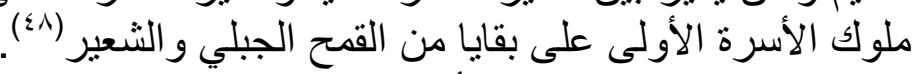

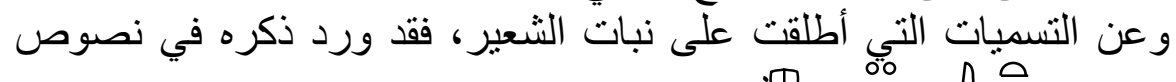

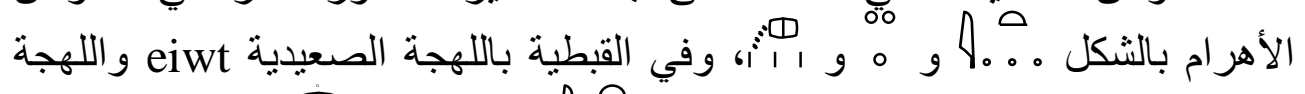

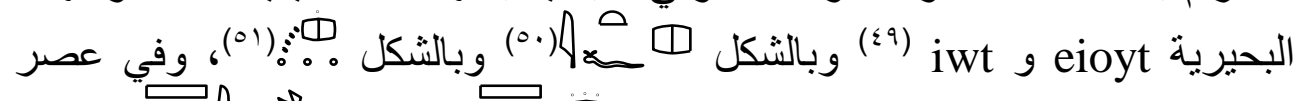
الدولة الوسطى وردت كلمة الثعير بالشكل ضَث:

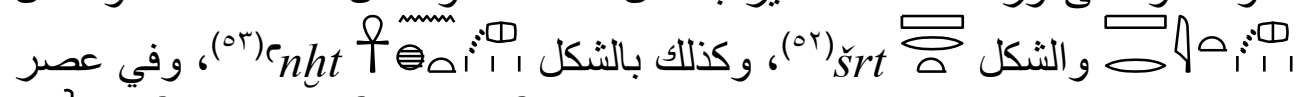

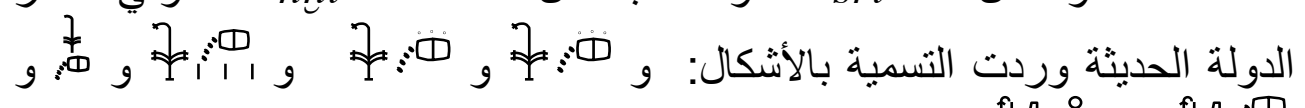

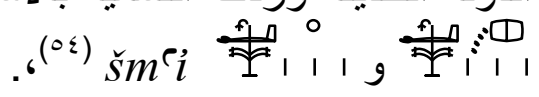

وفي العصر اليوناني الروماني كتبت كلمة Šrt بالشكل

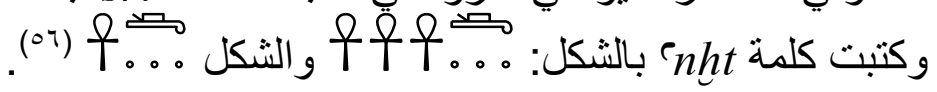

و الملاحظ في الكتابات السابقة الدالة على تسمية نبات الثعير أن معظمها أخذ

مخصص هـ: "مكيال الحبوب" مثل معظد الكلمات كلمات نبات القمح والتي ربما

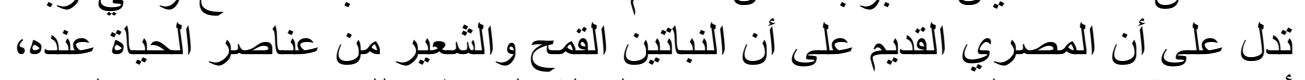

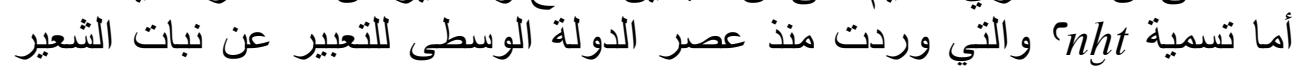


فربما تعنى "النبات الذي يعطى الحياة"، و هذا ما أورده المصري القديم أيضًا بالنسبة

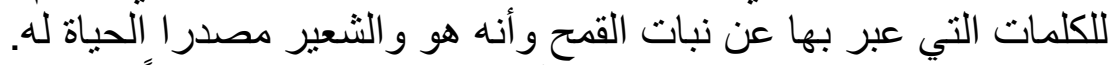

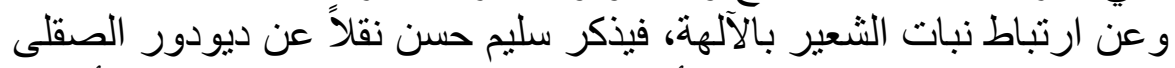

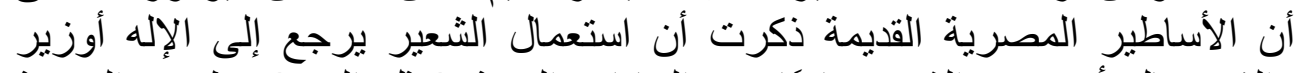

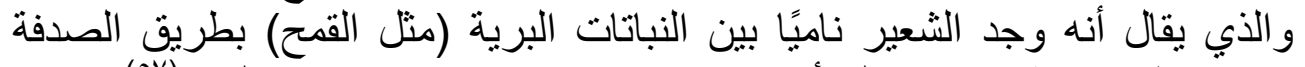

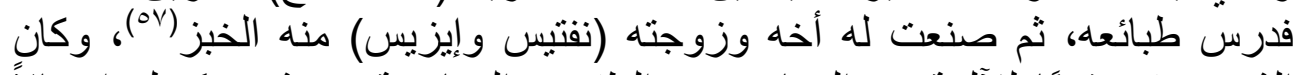

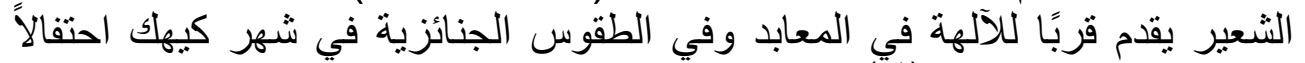

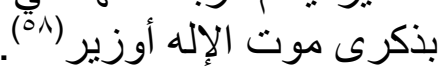

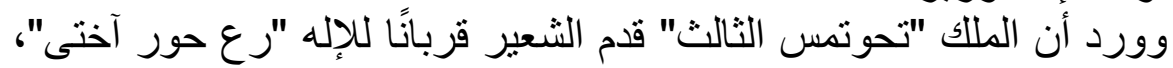

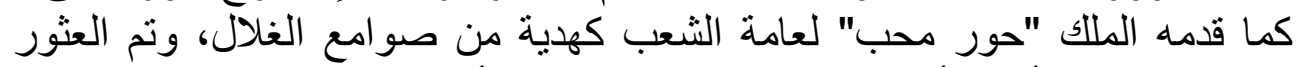

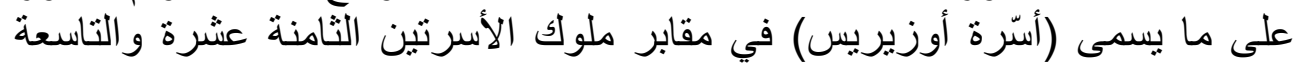

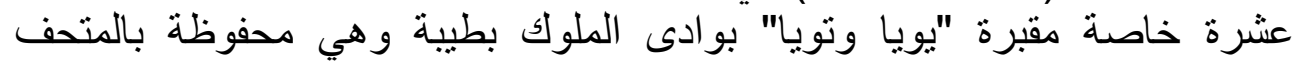

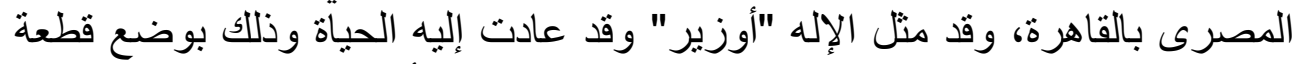

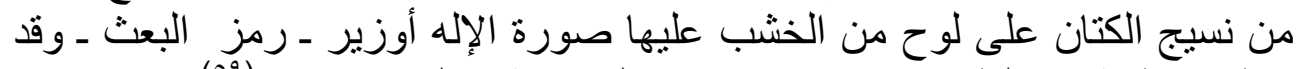

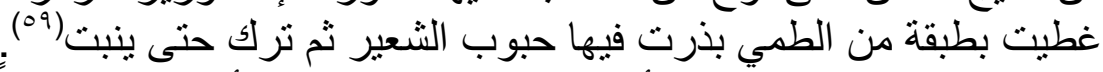

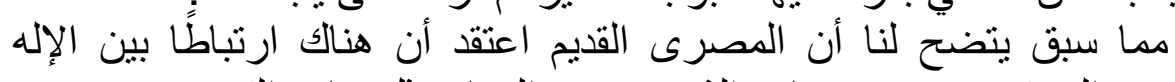

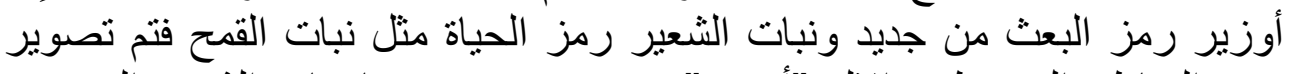

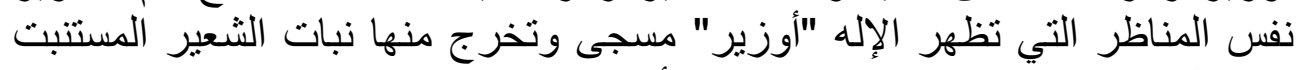

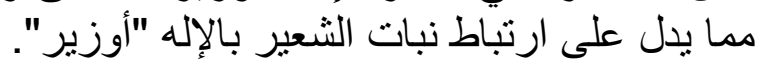

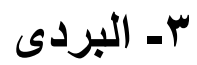

كان البردى ينمو وينتشر في مستنقعات الدلتاو على جانبي مجرى نهر النيل، التهات

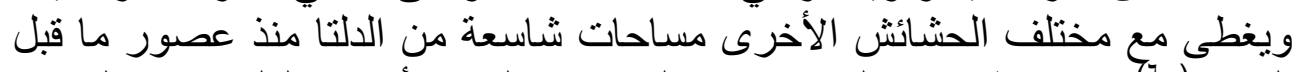

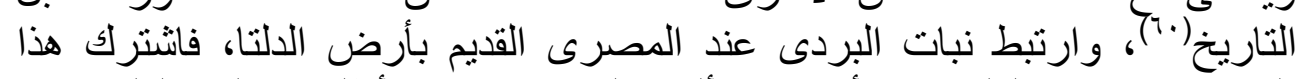

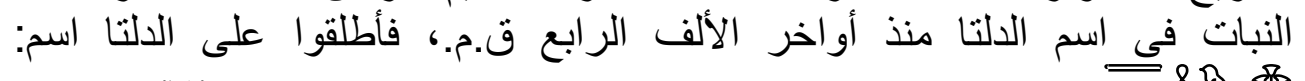
مأه

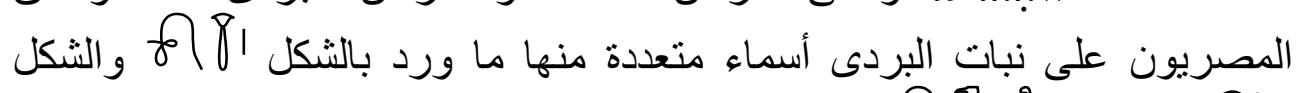
w3

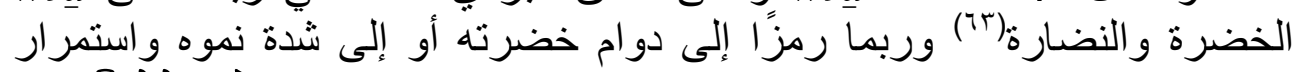

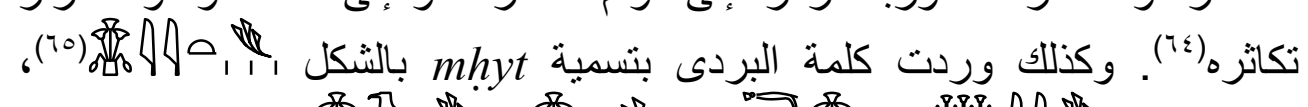
وبالأشكال:

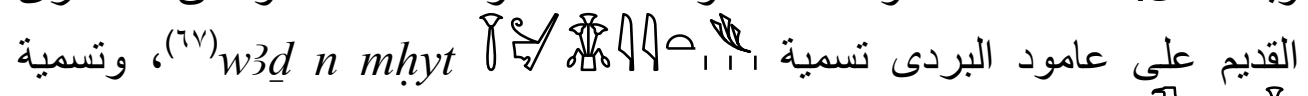

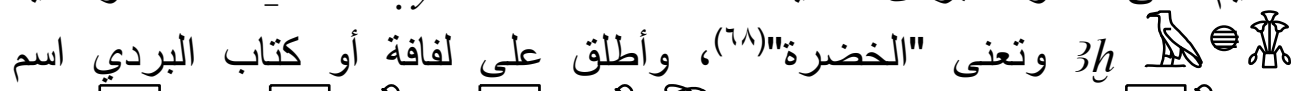

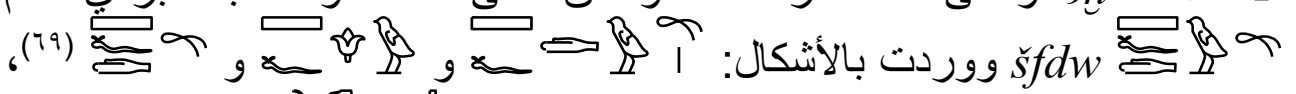

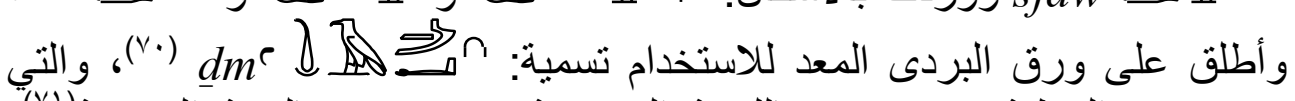

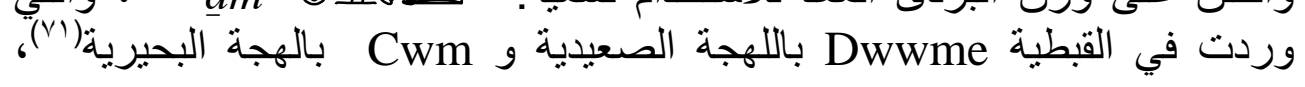




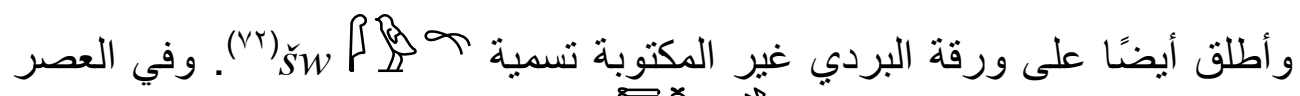

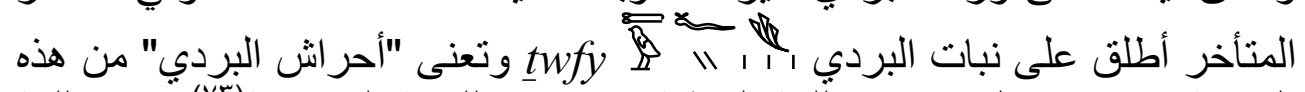

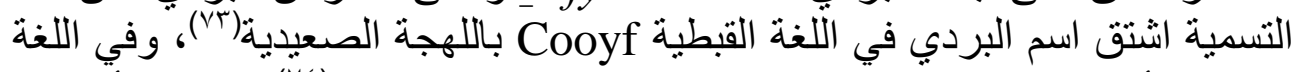

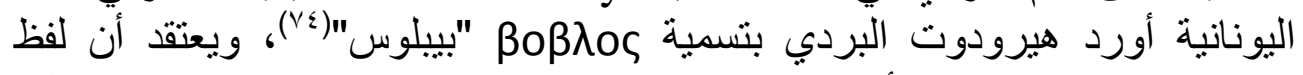

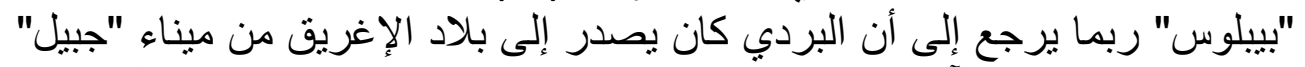

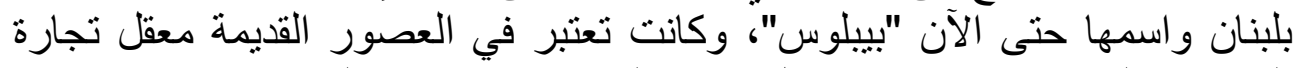

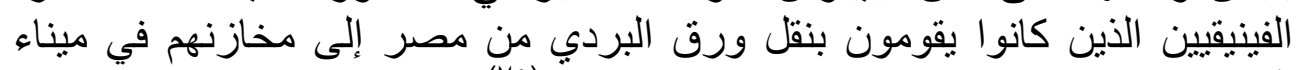

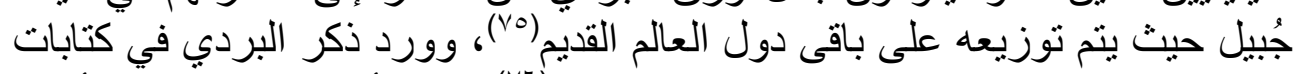

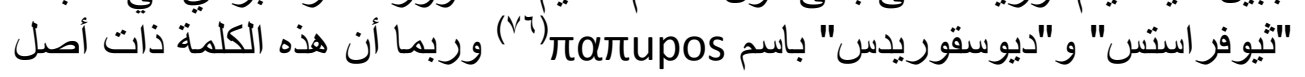
مصرى قديم للكلمة:

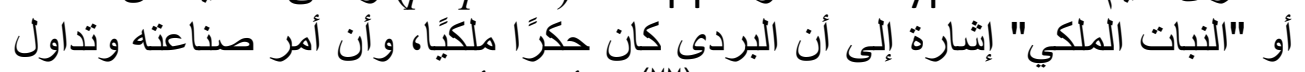

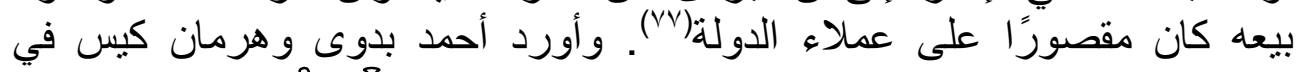

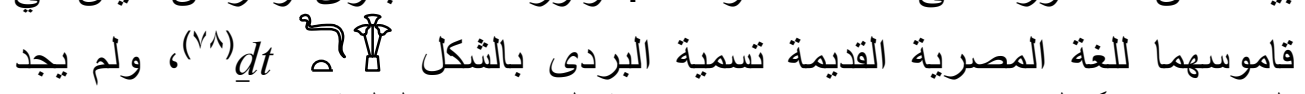

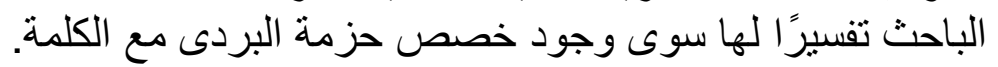

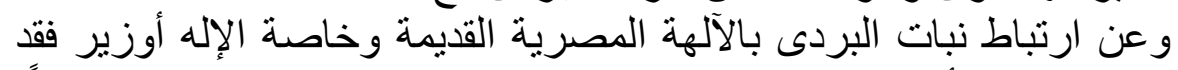

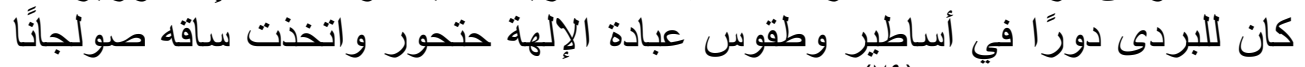

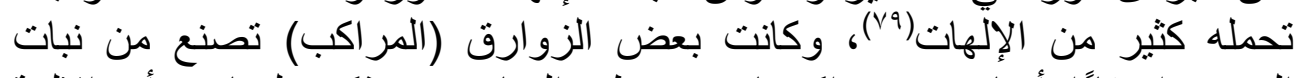

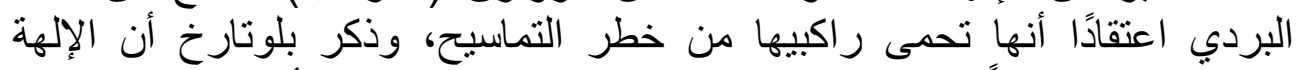

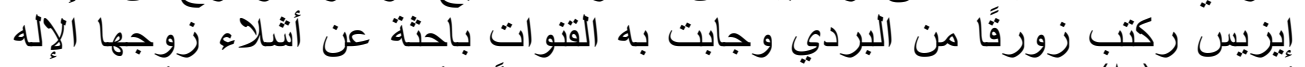

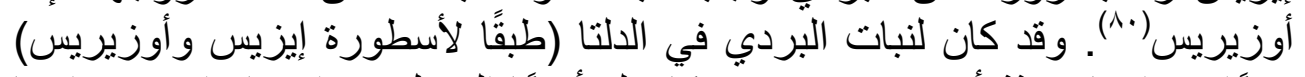

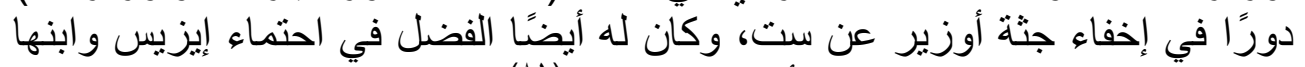

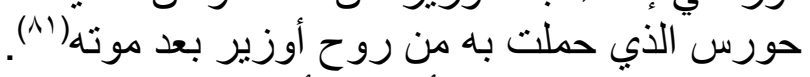

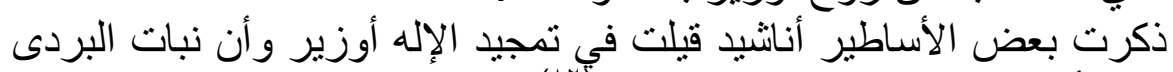

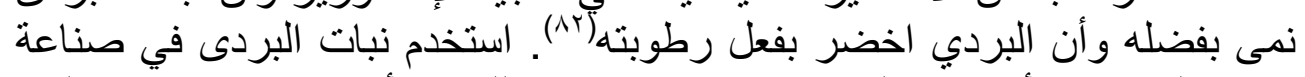

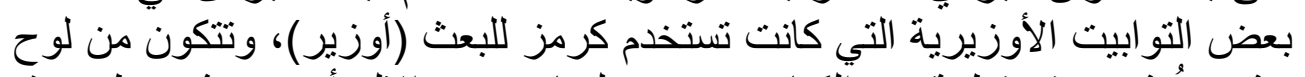

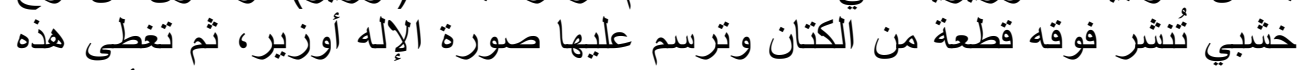

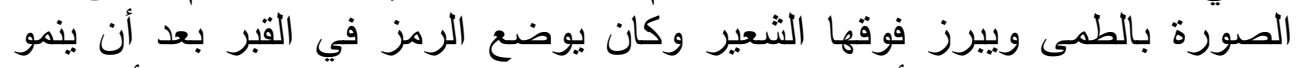

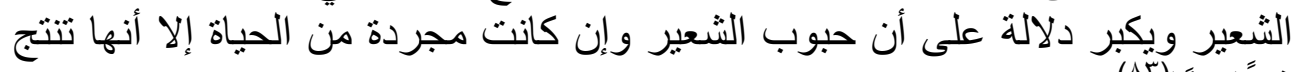

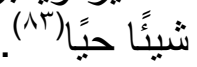

مما سبق بتضح لنا أن المصرى القديم أدرك مدى ارتباط نبات البردى بالإله

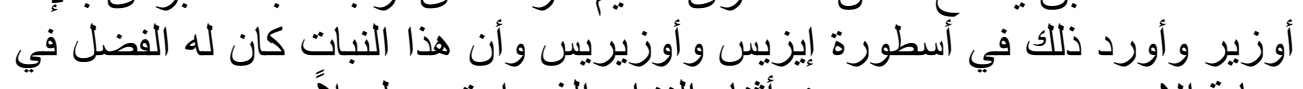

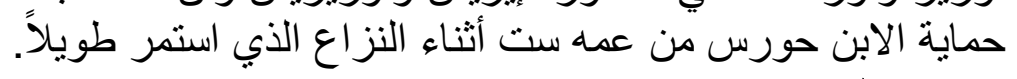
ع- الكتان : الابن جورن

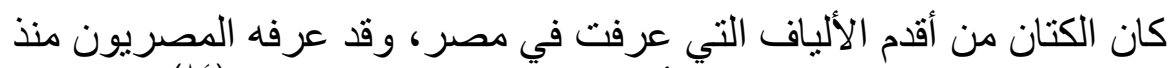

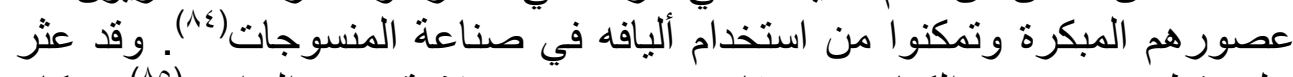

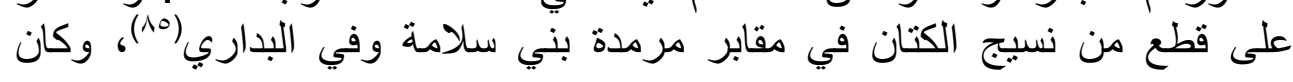




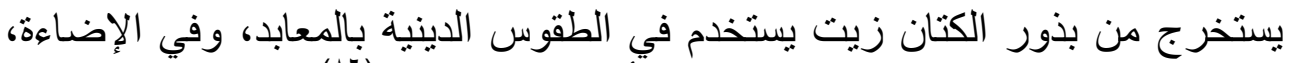

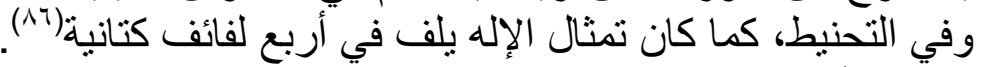

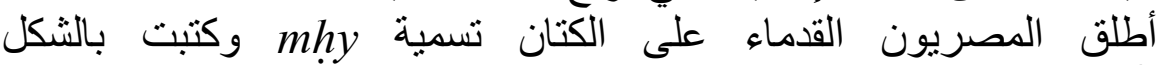

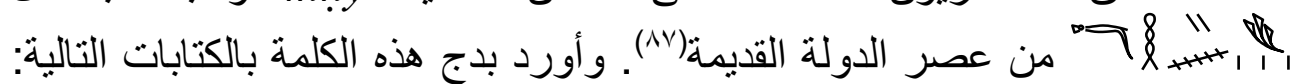

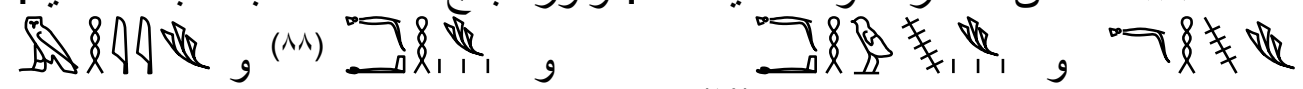

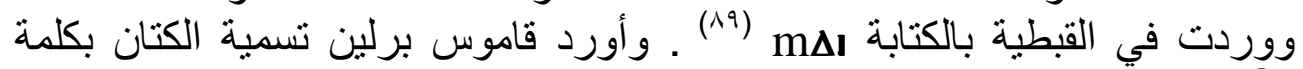

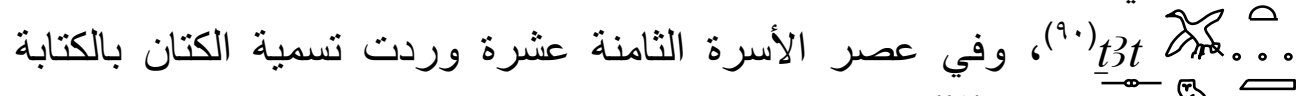

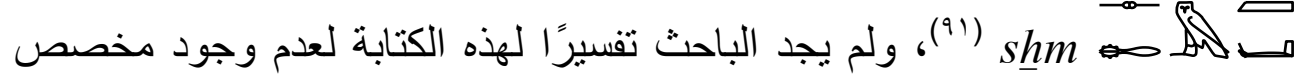

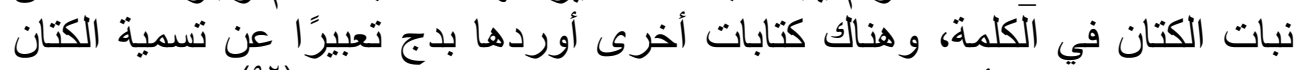

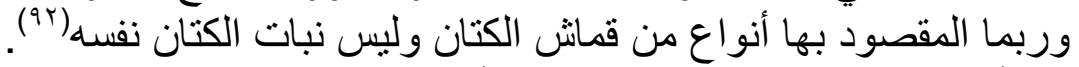

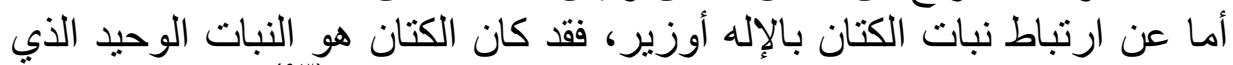

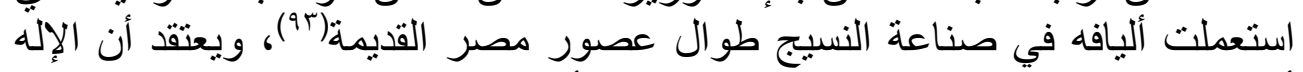

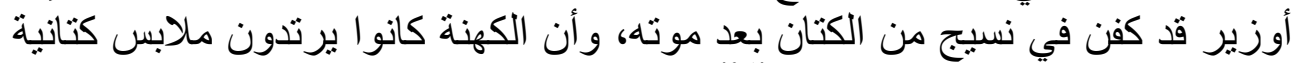

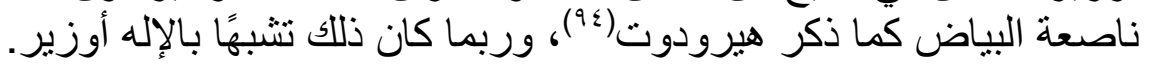

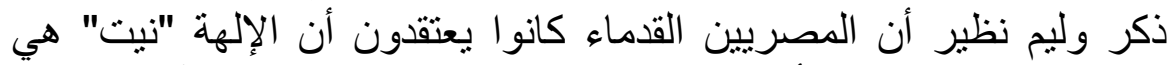

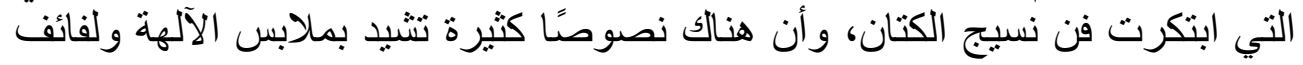

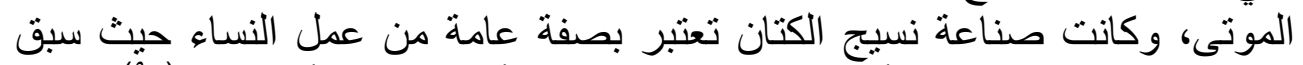

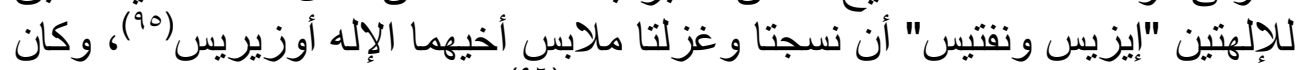

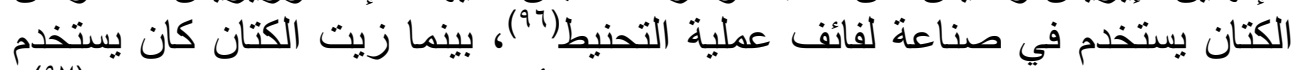

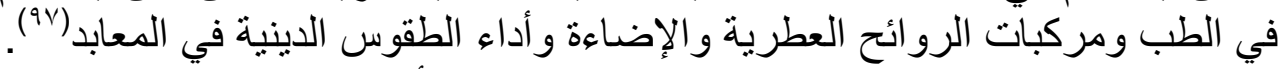

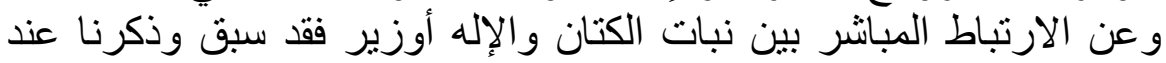

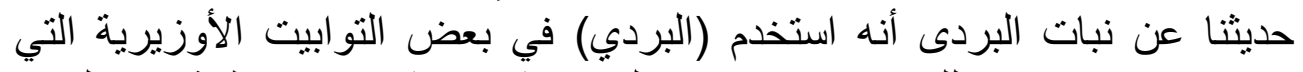

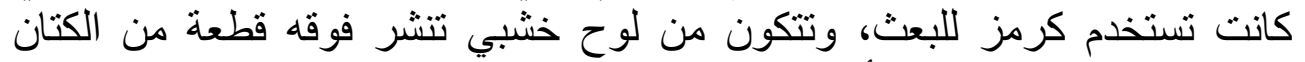

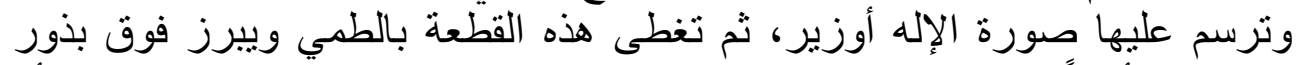

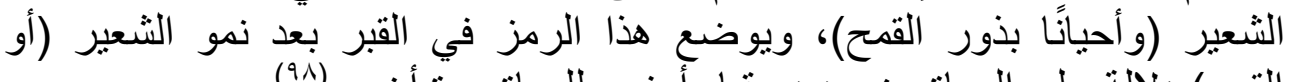

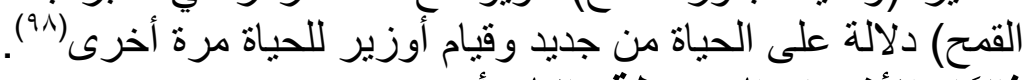

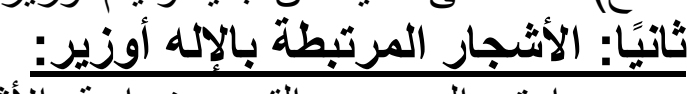

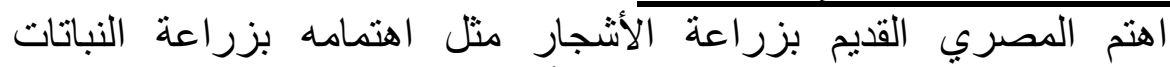

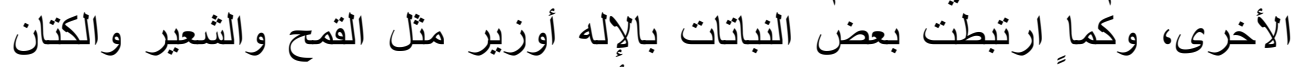

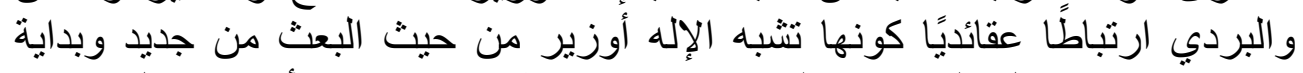

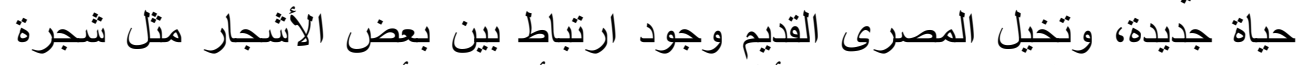

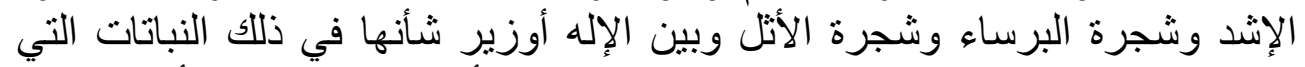

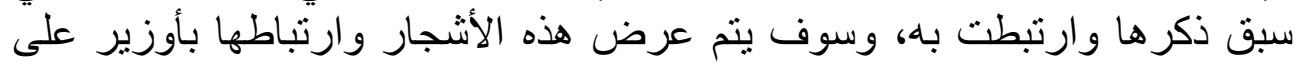
النحو التالي: - النيا:

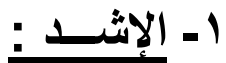




\section{النباتات والأشجار المرتبطة بالإله أوزير}

عرفت شجرة الإشد في اللغة المصرية القديمة وكتبت بعدة أشكال منذ عصر

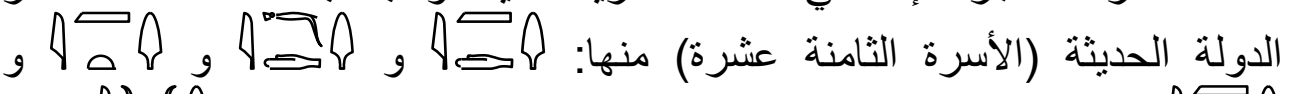

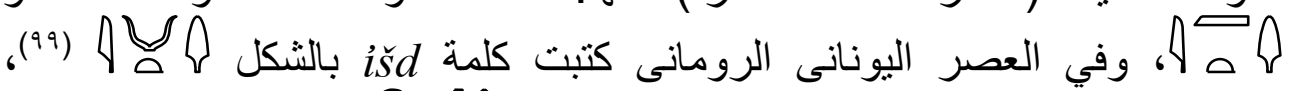

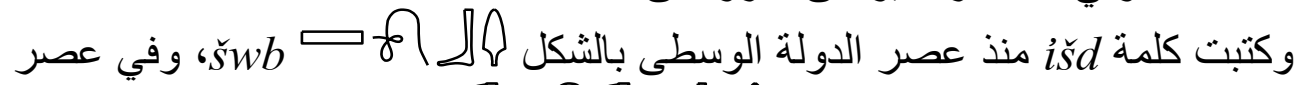

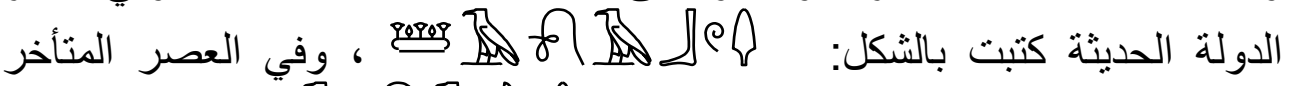

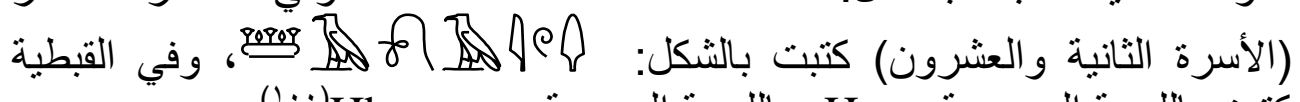
كتبت باللهجة الصعيدية Hoye وباللهجة البحيرية كان المصريون القدماء يأكلون ثمار شجرة الإشد، ويصنعون من أغدئه أغصانها الأكاليل الجنائزية، ويستخدمون خشبها في البناء والصناعة و عمل مقابض السكاكين و الحراب ويستخرجون منها أليافًا لصنع الحبال، وقد قدست هذه الثجرة للإله

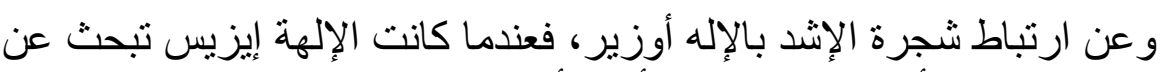
أوزير (1.)

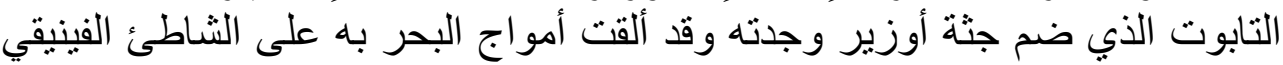
عند جبيل (ببلوس)، وسقط التابوت بجوار شجرة (شجرة الإشد) سر عان ما نمت

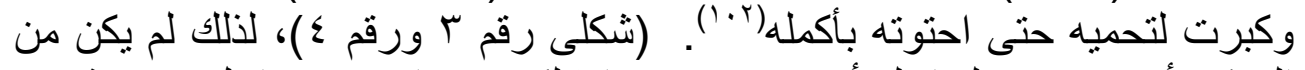
الممكن أن يتحقق مولد الإله أوزير من جديد إلا لكونه قد انحصر بداخل جز

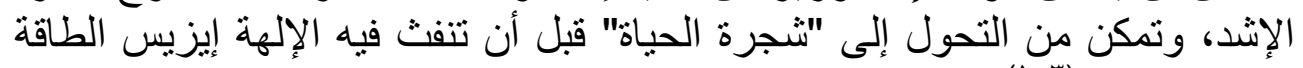

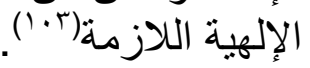

و عن قدسية شجرة الإشد عند المصري القديم يذكر عبد المنعم أبو بكر أنه بعد أن تتم مر اسيم تتويج الملك، كان يجلس تحت شجرة الإشد ليقوم كل من الإله

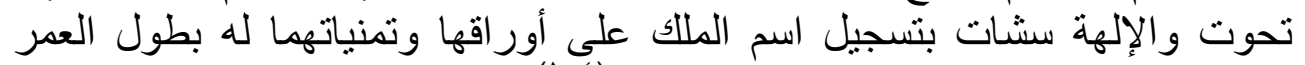

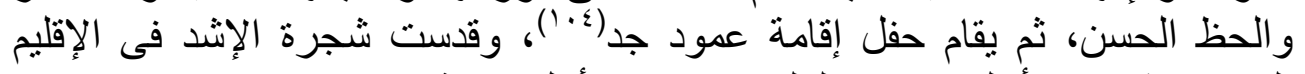
السابع عثر من أقاليم مصر العليا، واستخدم أهل مدينة "ساو" (سايس) زيوتها في

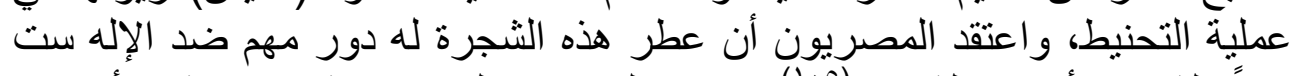

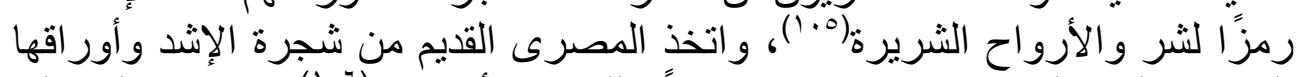

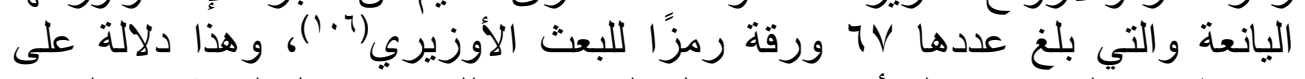

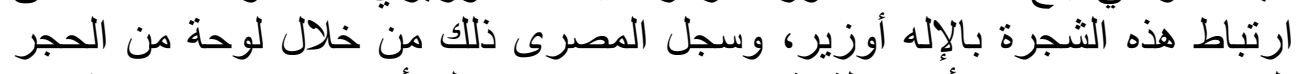

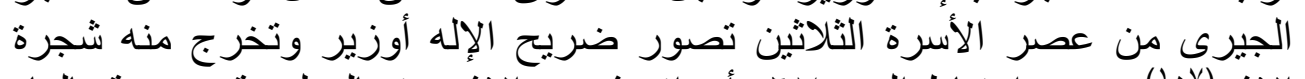

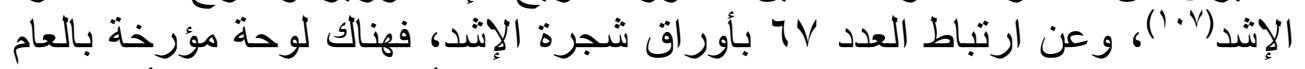

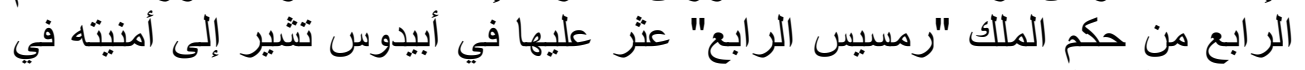

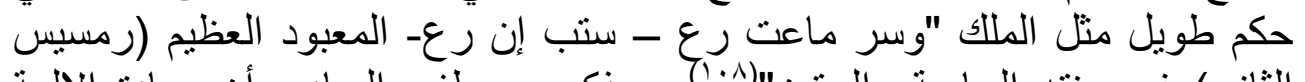

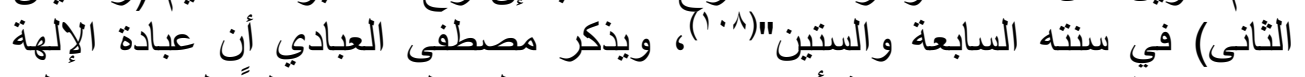

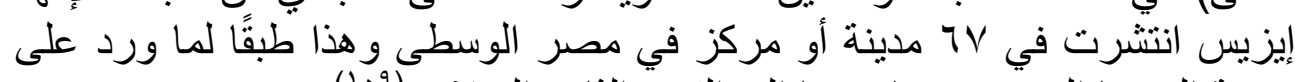

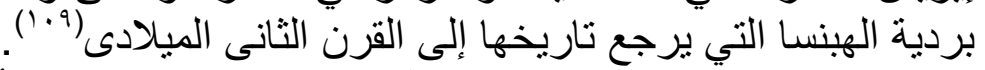

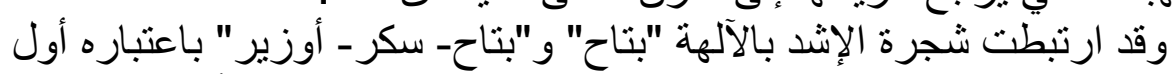

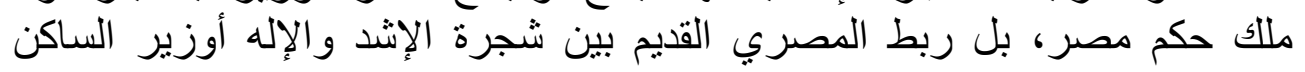


(القاطن) في حمايتها يوم دفنه (التابوت) ثبَّعا لاحتفالات الإله أوزير في شهر كيهاتك

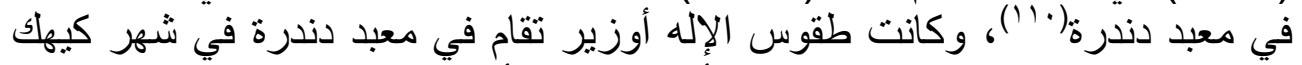

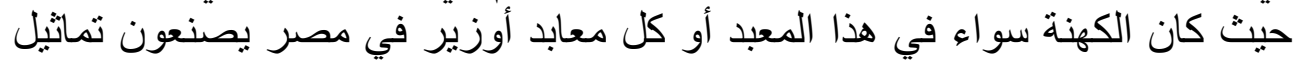

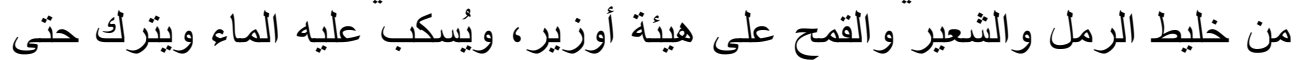

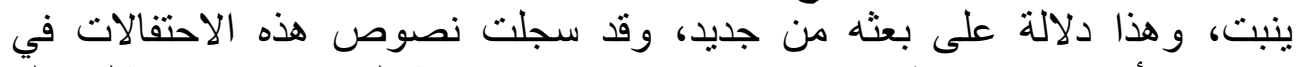

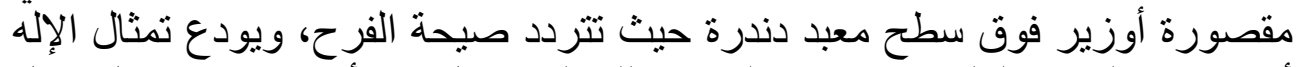

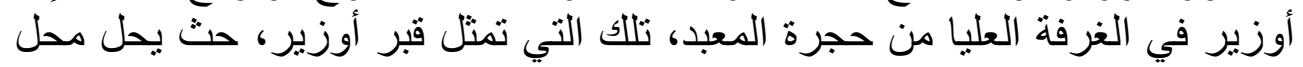

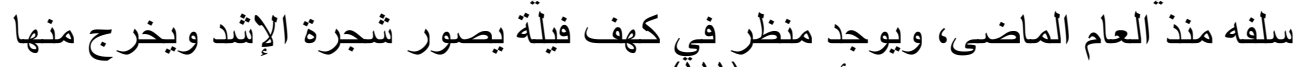

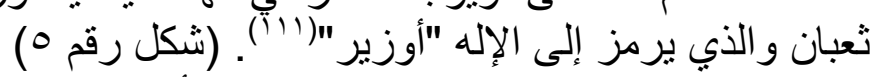

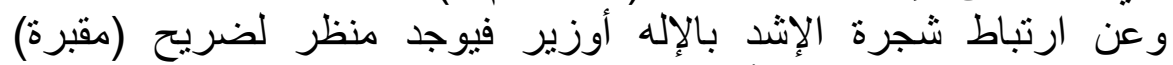

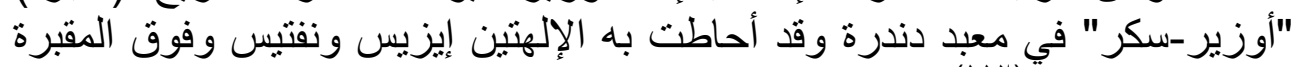

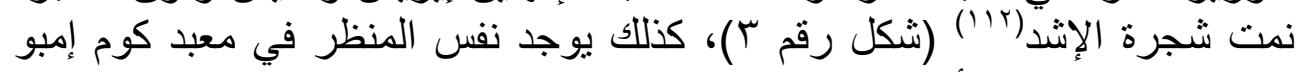

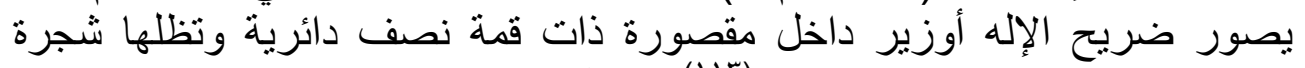

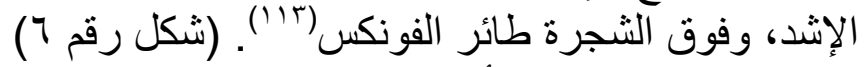

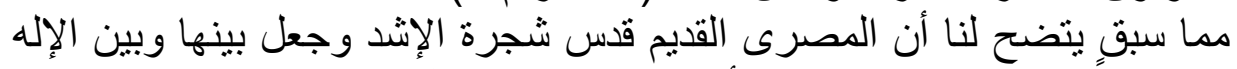

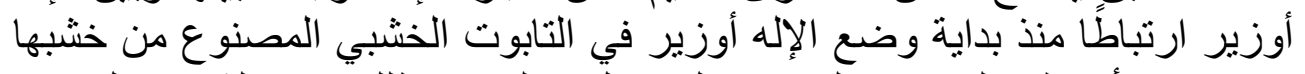

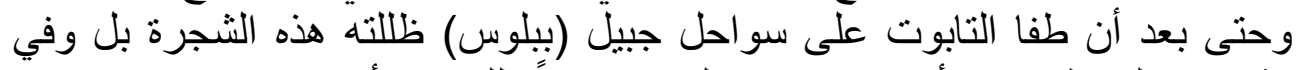

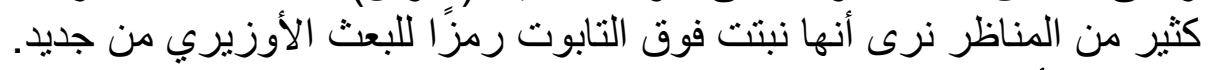

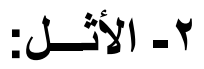

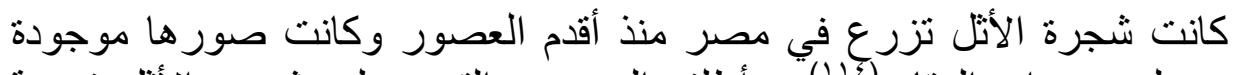

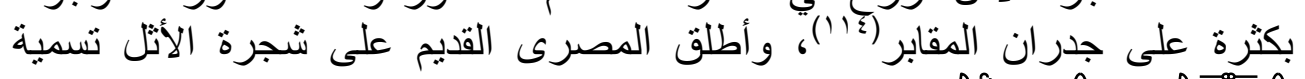

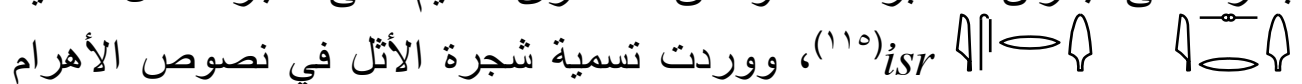

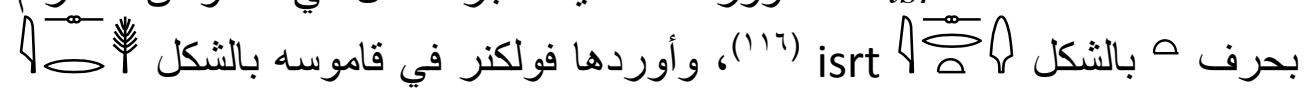

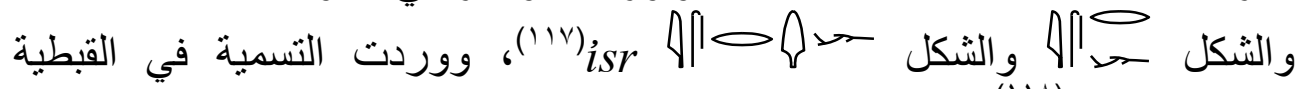

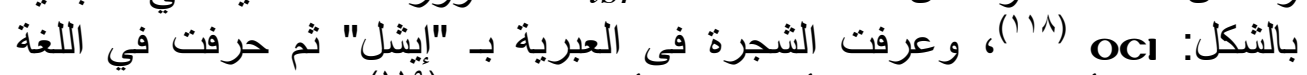

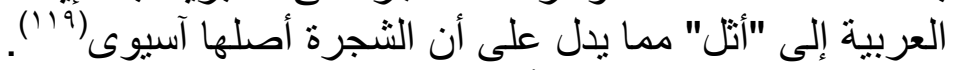

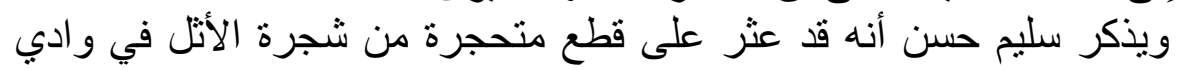

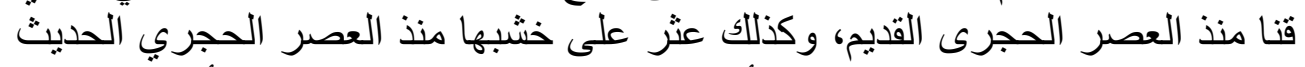

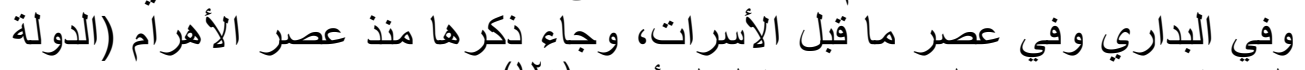

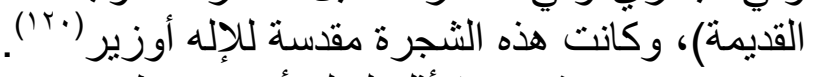

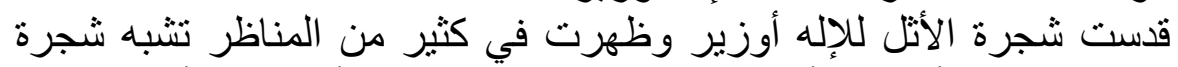

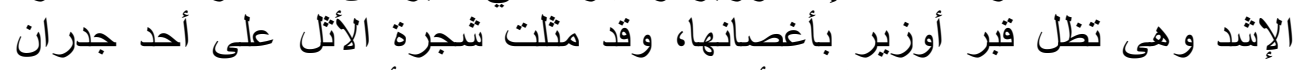

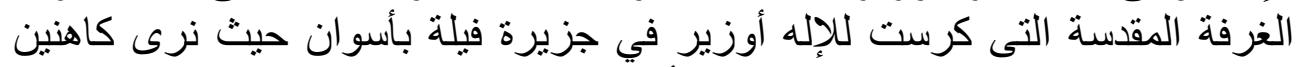

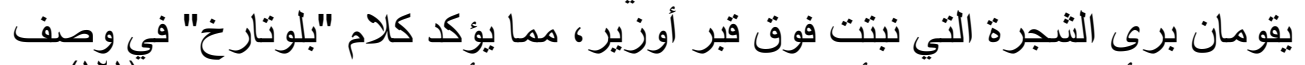

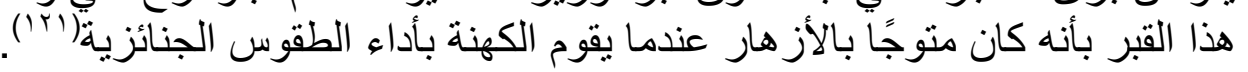


مما سبق يتضح لنا أن المصري القديم ربط شجرة الأثل بالإله أوزير من خلال

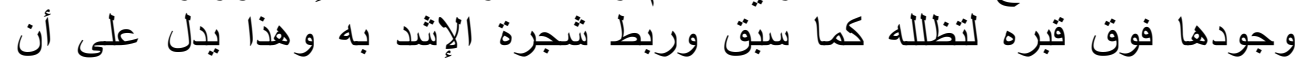
الشجرتين كانتا مقدستين وارتبطت فئنا بالإله أوزير.

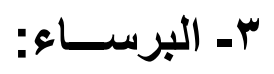

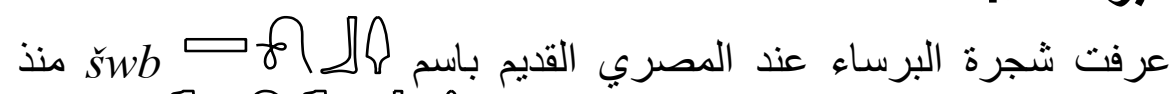

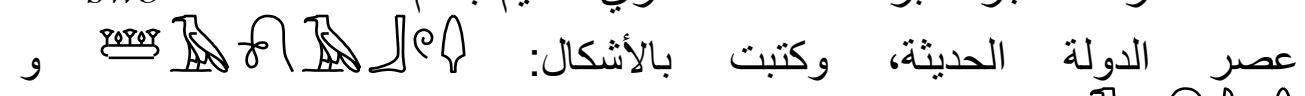

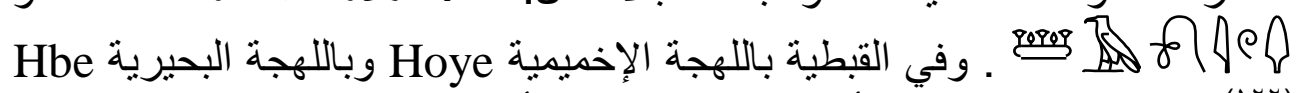

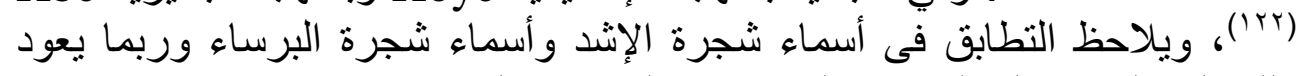

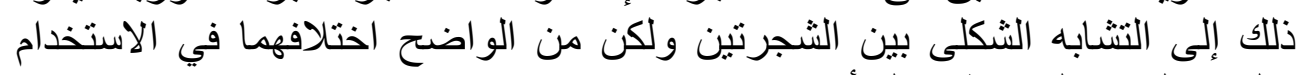

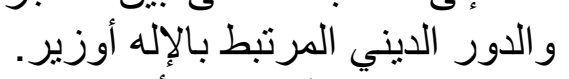

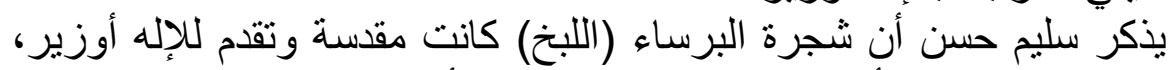

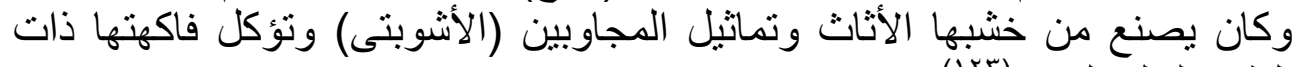

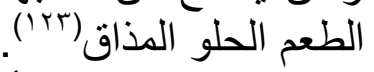
يرى الباحث أن صناعة تماثيل المجاوبين (الأوشبتى) من خثب شبن شجرة

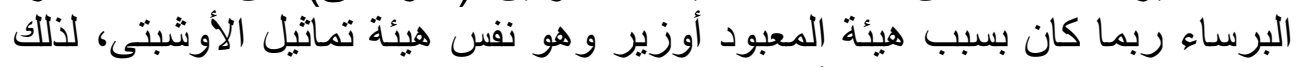

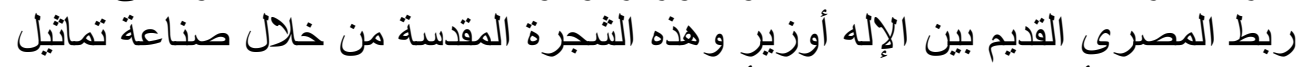

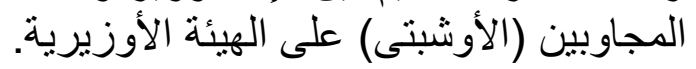

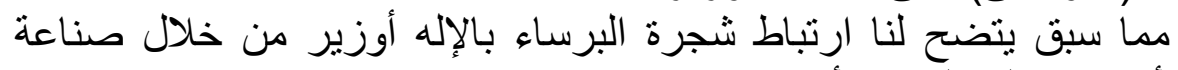
تماثيل الأوشبتى على الهيئة الأوزيرية. الخاتمة

يتضح لنا بعد هذا العرضٍٍ للنباتات والأشجار التي قدسها المصرى التهر القديم

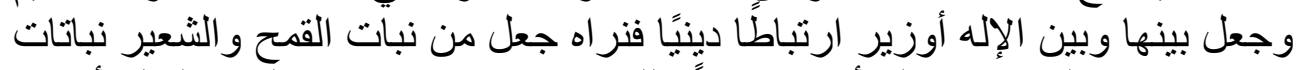

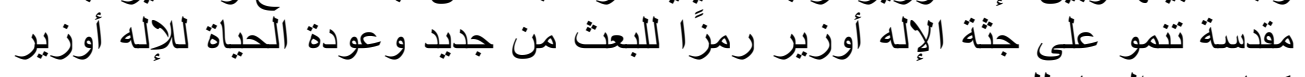

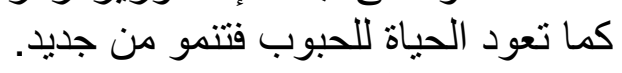

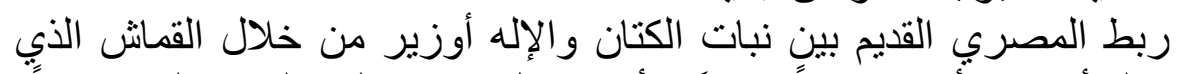

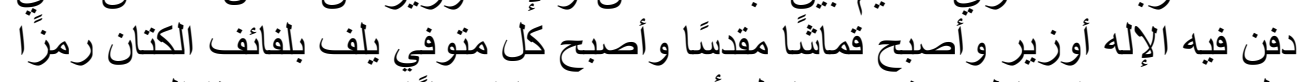

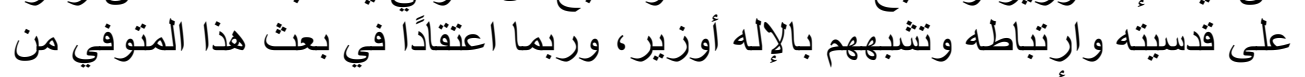

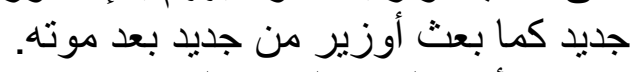

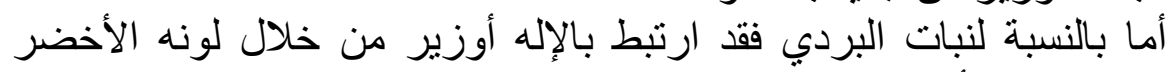

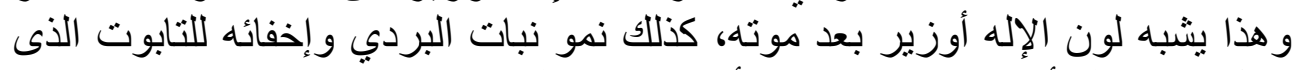

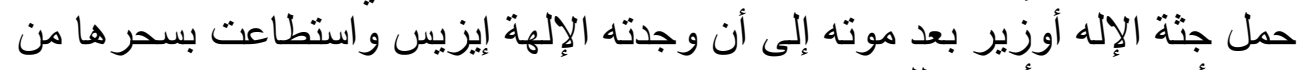

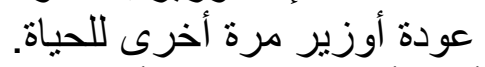
أما الأشجار الإشد والأنتل و البرساء فكلهاء ألهاء جعلها المصري القديم ترتبط بالإله أوزير

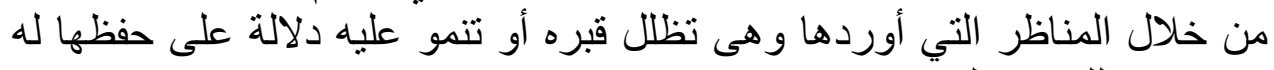

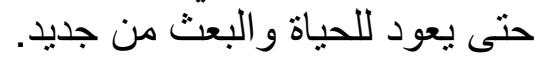

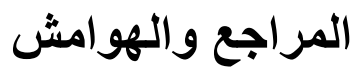


1- BIFAO : Bulletin de Instit Francais d'archéologie orientale (Le Caire).

2- JGS : Journal of Glass Studies Corning Mus. of Glass (New York).

3- L̈̈ : Lexikon der Ägyptischen (Wiesbaden).

4- Pyr : K. Sethe, Die altägyptischen Pyramidentexte nach den Papierabdrücken und photographien des Berliner Museums neuherausgegeben und erläutert (Leipzig).

5- Urk : Urkunden des Ägyptischen Alterums, IV, 1-16 Sethe K. der 18 Dynastie, Berlin, 1961.

6- Wb, : Erman A \& Grapow H., Wörterbch der ögyptischen Sprache, 6 vols. $3^{\text {rd }}$ ed. Berlin, 1961- 71.

عبد الحليم نور الدين: الديانة المصرية القديمة، الجزء الأول، المعبودات، القاهرة،

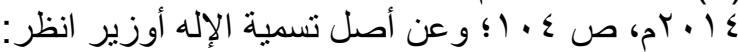

Griffiths, J. G., Osiris, LÄ IV, pp. 623- 625.

رندل كلارك: الرمز والأسطورة في مصر القديمة، ترجمة أحمد صليحة، القاهرة،

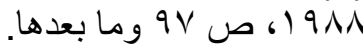

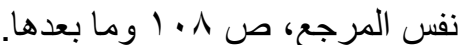

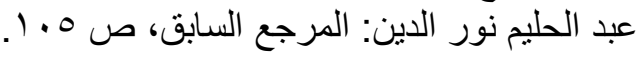

(5) Goyon, J. C., Le Cérmonial De Glorifcation D'Osiris Du Papyrus Du Louvre I. 3079 (Colonnes 110 À 112), BIFAO 65 (1967), 89- 156;

Griffiths, J. C., LÄ, pp. 628- 629.

$$
\text { وعن ارتباط الإله أوزير بالآلهة الأخرى انظر: }
$$

أحمد فخرى: أباتون، الموسوعة المصرية، تاريخ مصر القديمة وآثارها، المجلد الأول،

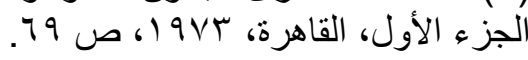

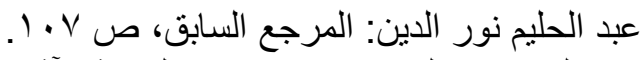

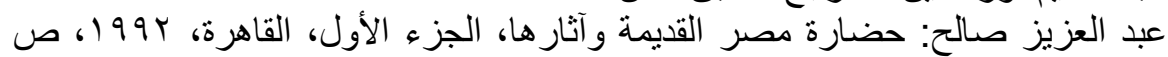

أحمد أمين سليم وسوزان عباس عبد اللطيف: دراسات في تاريخ وحضارة الثرق القديم

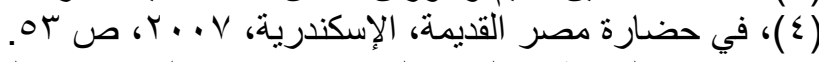

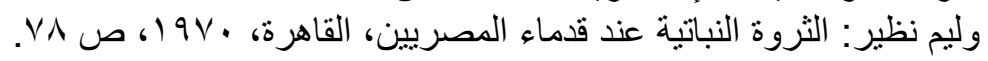

(11) Wb, l, 386- 14.

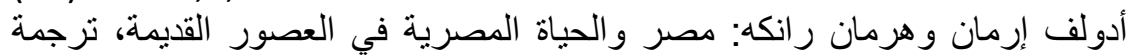

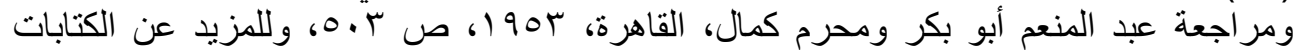

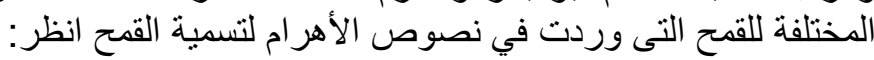
Pyr., 657, 761, 874, 1950, 2070.

(13) Wb, III, 426- 12.

أحمد أمين سليم وسوزان عباس عبد اللطيف: المرجع السابق، ص به؛ وليم نظير:

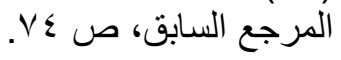




\section{النباتات والأشجار المرتبطة بالإله أوزير}

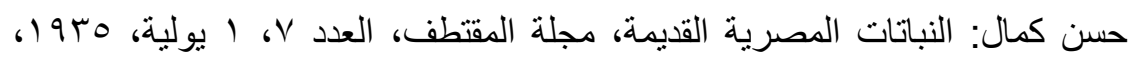

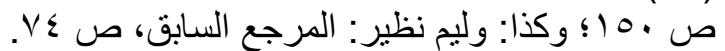

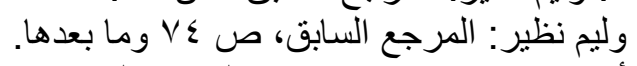

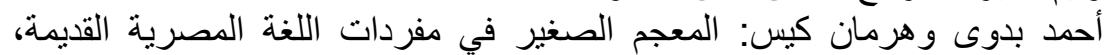

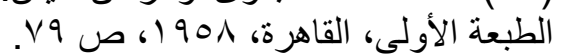

حسن خطاب: الثروة النباتية عند المصريين القدماء، القاهرة، 9Vو اه، ص 99 و وما

بعدها

(19) Budge, W. A., An Egyptian Hieroglyphic Dictionary, vol. I, New York, 1987, p. 468 a.

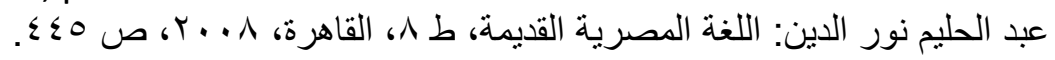

(21) Budge, W. A., op. cit., p. 242 b.

(22) Ibid., p. 126 a.

(24) Budge, W. A., op. cit., p. 50 b.

$$
\text { أحمد بدوى و هرمان كيس: المرجع السابق، ص }
$$

(25) Ibid., p. 523 b.

(26) Ibid., p. 529 a.

(27) Ibid., p. 559 b.

(28) Ibid., II, p. 788 b.

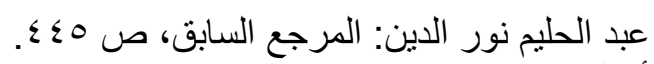

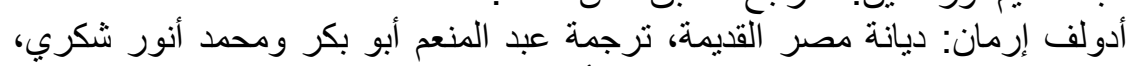

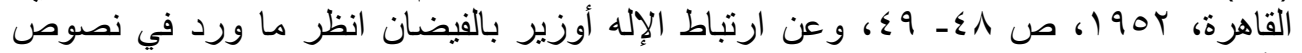

Pyr., 25- 589- 767.

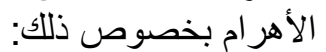

$$
\text { أدولف إرمان: المرجع السابق، ص } 9 \text { ؟، وكذا: }
$$

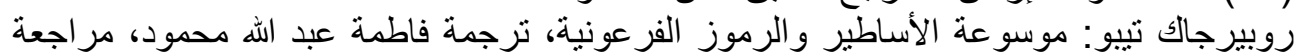
(32) Pyr., 388.

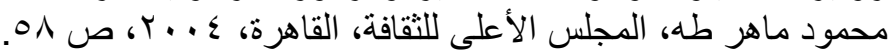

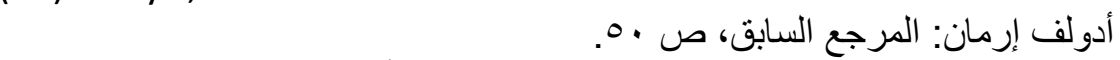

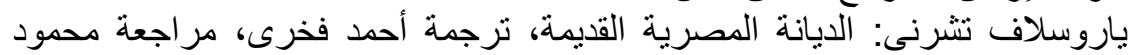

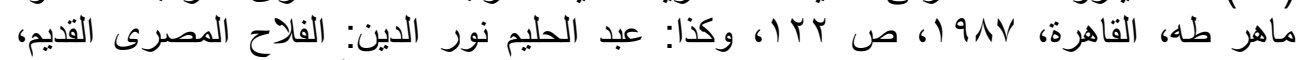

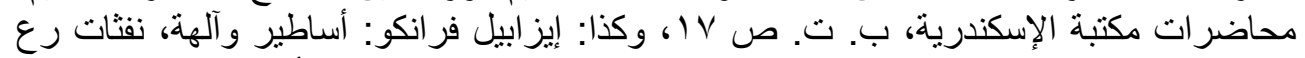
إله الثمس، ترجمة حليم طوسون، مراجعة محمود ماهر طالاه، المجلس الأعلى للثقافة، القاهرة،

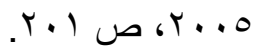

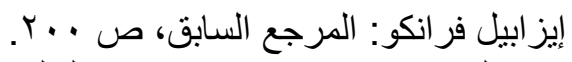

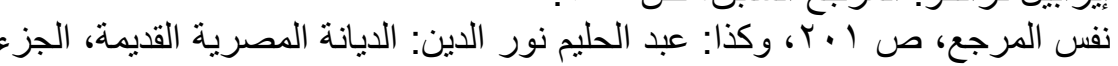

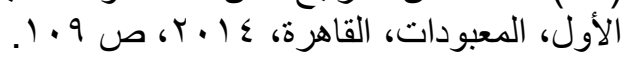

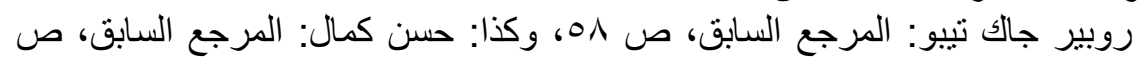

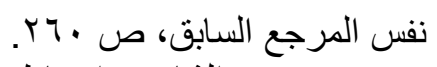

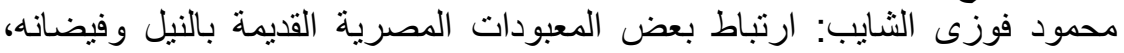

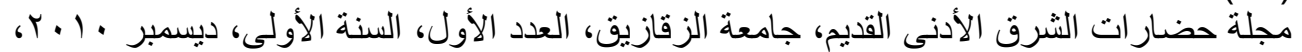

$$
\text { روبير جالك تيبو: المرجع السابق، ص }
$$




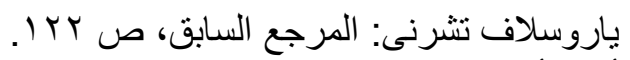

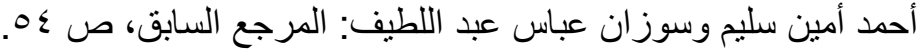

نجيب ميخائيل: الزراعة، تاريخ الحضارة المصرية، العصر الفرعوني، المجلئ المجلد الأول،

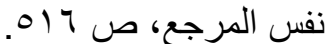

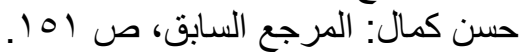

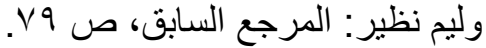

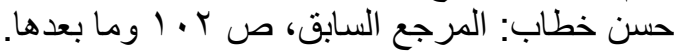

$$
\begin{aligned}
& \text { حسن كمال: المرجع السابق، ص لـ } 10 \text { وما بعدها. }
\end{aligned}
$$

(49) Wb, I, 142-1.

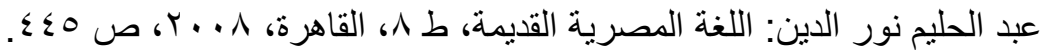

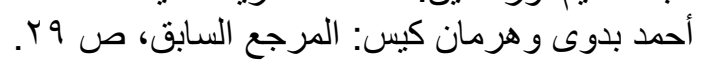

(52) Wb, IV, 524- 2;

أحمد أمين سليم وسوزان عباس عبد اللطيف: المرجع السابق، ص ؟0.

(53) Wb, I, 205- 10.

(54) Wb, IV, 476- 8.

(55) Wb, IV, 524- 2.

(56) Wb, l, 205- 10.

(OV) مليم حسن: مصر القديمة، الجزء الثنانى، في مدنية مصر وثقافتها في الدولة القديمة

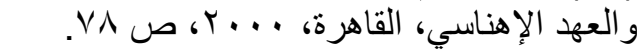

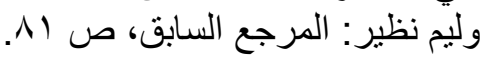

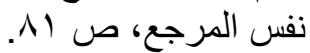

محمد محمد الصغير: البردي واللونس في الحضارة المصرية القديمة، القاهرة،

(62) Wb, I, 263- 7.

(63) Wb, I, 264-8, 11.

(64) Pyr., $1530 \mathrm{~b}$.

(65) Wb, II, 124- 8.

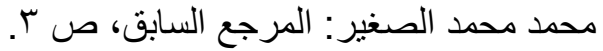

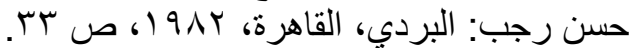

(68) Gardiner, A., Egyptian Grammar, $3^{\text {rd }}$, ed., London, 1973, p. 481, M 15; Faulkner, R. O., A Concise Dictionary of Middle Egyptian, Oxford, 1986, p. 4.

(69) Wb, IV , 461- 11;

(72) Wb, IV, 428- 5.

$$
\begin{aligned}
& \text { حسن رجب: المرجع السابق، ص هب. }
\end{aligned}
$$

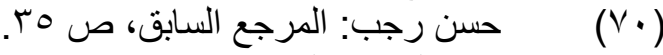

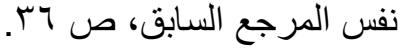

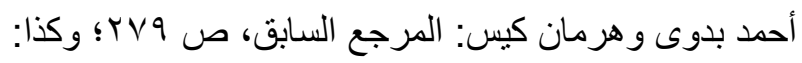

Crum, W. E., A Coptic Dictionary, Oxford, 1930, p. 795 a; Černy, J., Coptic Etymological Dictionary, London, 1976, p. 322. 
هيرودوت يتحدث عن مصر : ترجمة الأحاديث عن الإغريقية محمد صقر خفاجة، قدم

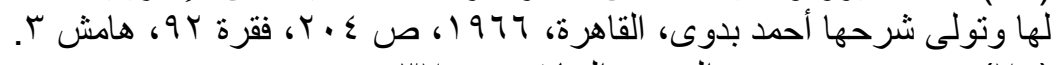

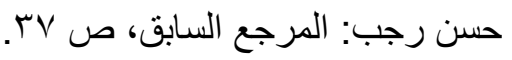

(76) Liddell, H. G. \& Scott, R. A., A Greek-English Lexicon, vol. II, Oxford, 1887- 1937, p. 1302.

(77) Černy, J., Paper and Books in Ancient Egypt, London, 1952, p. 4. حسن رجب: المرجع السابق، ص VI Vا، وللمزيد عن نبات البردى تسمياته واستخداماته انظر: محمد

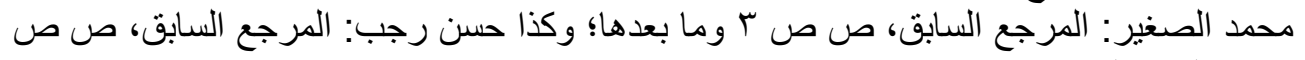
سب وما بعدها.

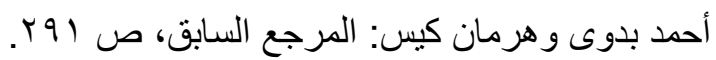

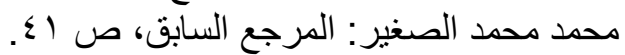

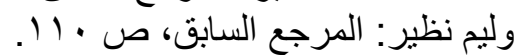

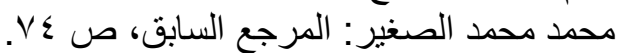

(82) Brugsh, H., Religion und Mythologie, Leipzig, 1885, pp. 613- 626.

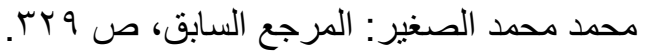

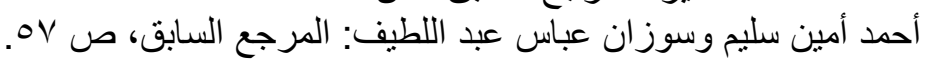

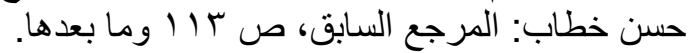

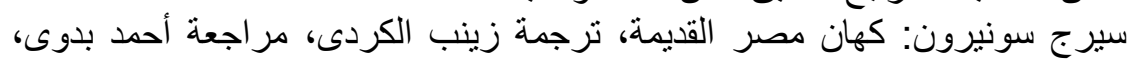

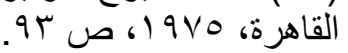

(87) Wb, II, 121- 4.

(88) Budge, W., l, $284 \mathrm{~b}$.

(89) Ibid., 319 a.

(90) Wb, V, 343- 6.

(91) Wb, V, 269- 12.

(92) Budge, W. I., 110 b- 136 a- 155 a- 252 a.

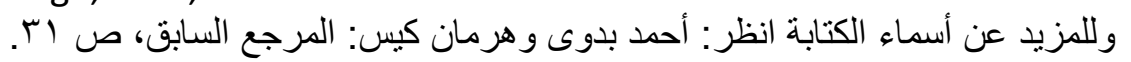

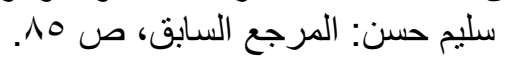

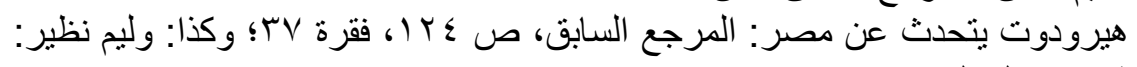

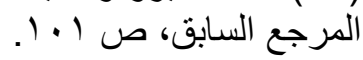

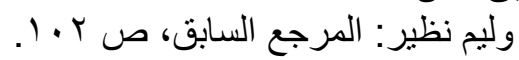

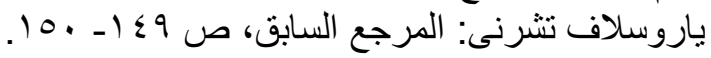

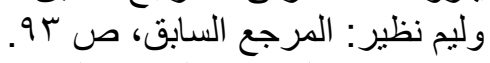

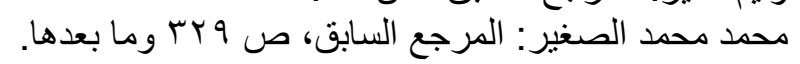

(99) Wb, I, 136- 506; Urk, IV, 591, 16; Faulkner, R. O., op. cit., p. 31. (100) Wb, IV, 435- 10.

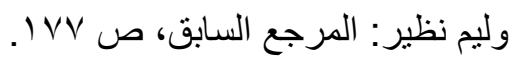

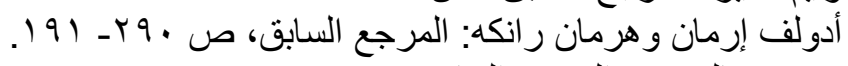

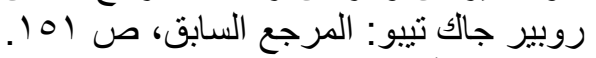

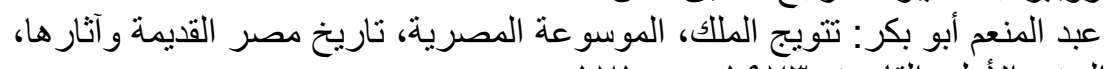

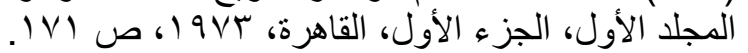

(105) R. el-Sayed, L'Isd de la Butte de la tombe d'Osiris, dans The Realm of the Pharaohs, Essay in honor of Tohfa Handoussa, vol. I, Cahier no 37,2009 , p. 232, n. 42. 


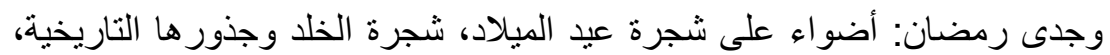

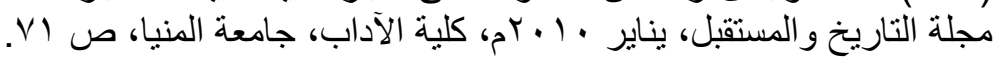

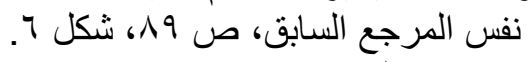

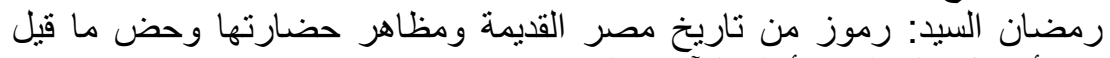

مصطفى العبادى: مصر من الإسكندر الأكبر إلى الفتح العربي، القاهرة، بول199 19،

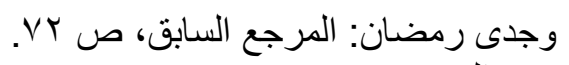

(112) R.el-Sayed, op. cit., p. 238, (doc. 4).

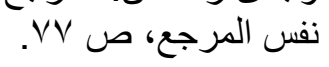

(113) Ibid., p. 238, (doc. 5).

(115) Wb, I, 130- 1.

(116) Wb, I, 130- 6

(117) Faulkner, R. O., op. cit., p. 31.

(118) Černy, J., op. cit., p. 122.

$$
\text { وليم نظير: المرجع السابق، ص IVI IV }
$$

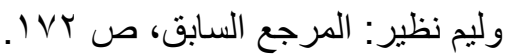

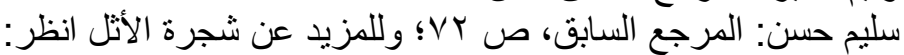

Sandford, The Policene \& Pliostocene Deposits of Wadi Qena in Quart, JGS, LXXXV (1929), p. 503.

(122) Wb, IV, 435- 10.

$$
\text { وليم نظير: المرجع السابق، صسVI. }
$$

$$
\text { سليم حسن: المرجع السابق، ص الV. }
$$


الأشكال و الصور

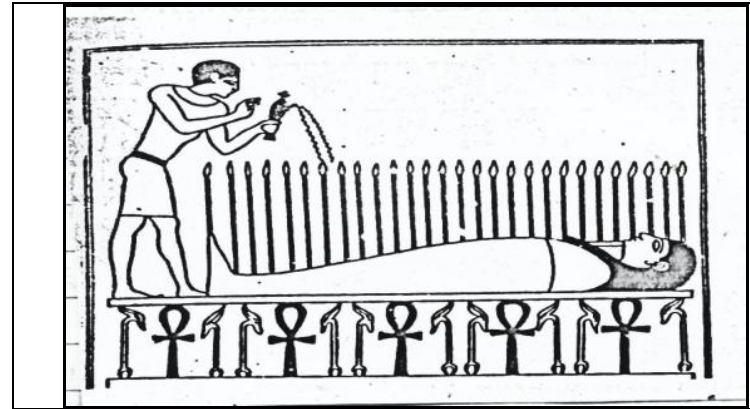

شكل رقم (Y): يمثل نباتات نامية من تابوت على هيئة

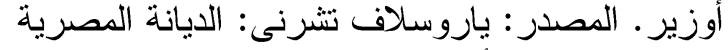

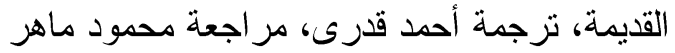

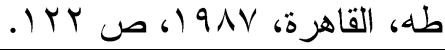

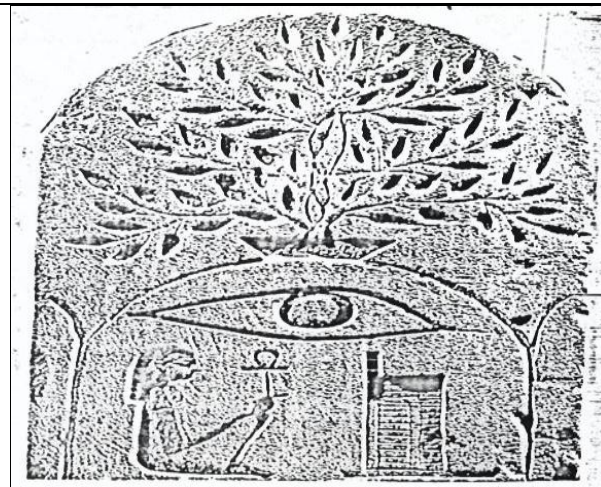

شكل رقم (؛): يمثل ضريح أوزير تخرج منه شجرة

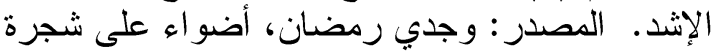

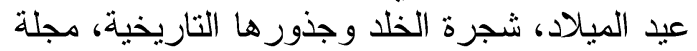

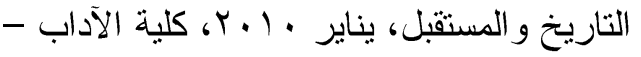
جامعة المنيا، ص 19 19، شكل بائ 1.

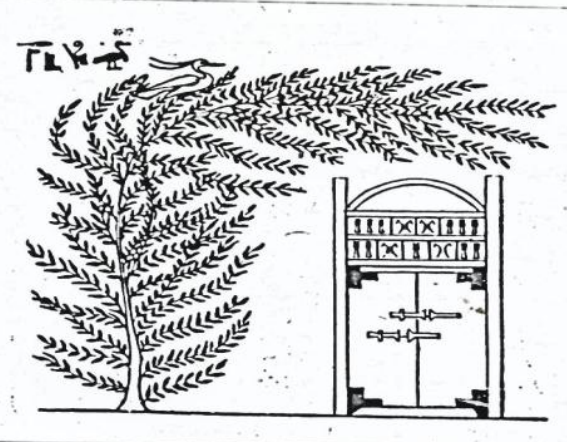

شكل رقم (ך): يمثل ضريح أوزير داخل مقصورة نصف دائرية وتظله شجرة الإثد. المصدر : نفس أنس

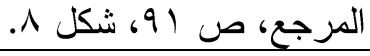

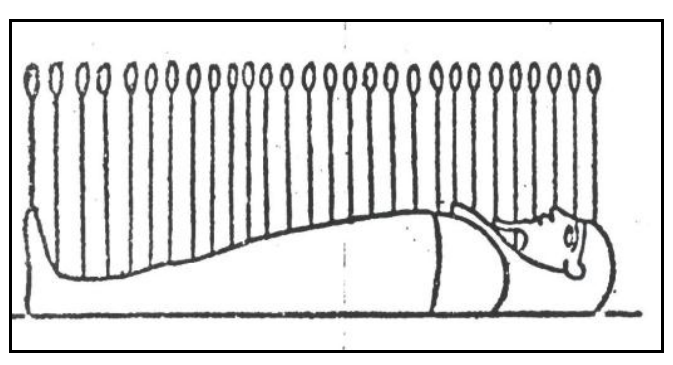

شكل رقم (1): يمنل جسد الإله أوزير ونمو النبات

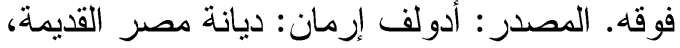
نزجمة عبد المنعم أبوبكر ومحمد أنور شكرى، ونه

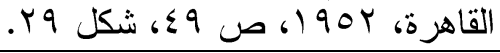

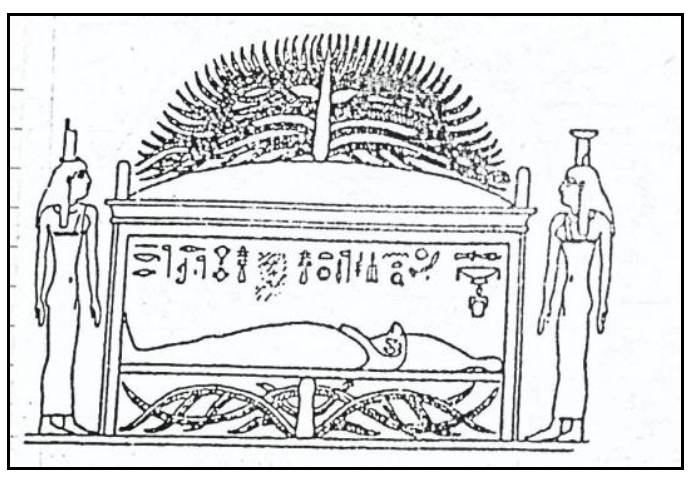

شكل رقم (r): يمتل نمو شجرة فوق تابوت أوزير إنمان

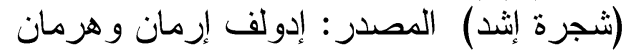

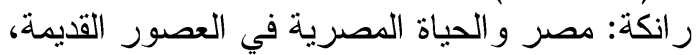

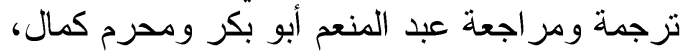

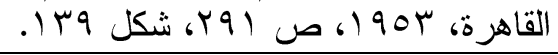

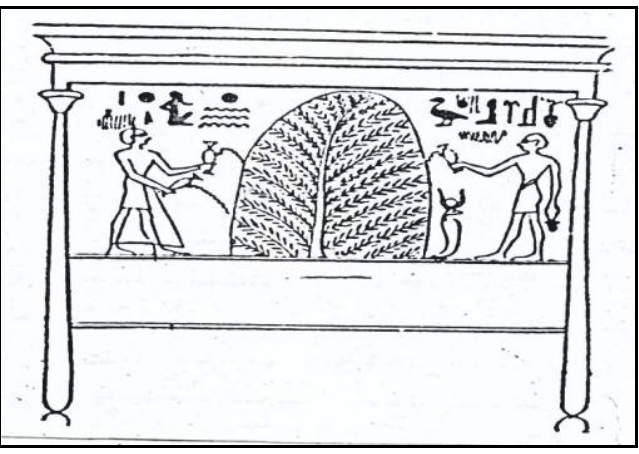

شكل رقم (0): يمنل أوزير على هيئة ثعبان يخرج

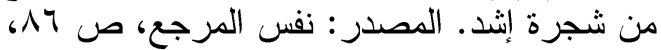

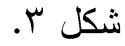

